\title{
Residential green space types, allergy symptoms and mental health in a cohort
}

\section{of tree pollen allergy patients}

http://doi.org/10.1016/j.landurbplan.2021.104070

\begin{abstract}
MICHIEL STAS $^{\mathrm{a}, \mathrm{b}, *}$, RAF AERTS $^{\mathrm{a}, \mathrm{c}, \mathrm{d}, \mathrm{e}, \mathrm{f}}, \quad$ MARIJKE HENDRICKX $^{\mathrm{f}}$ NICOLAS DENDONCKER $^{\mathrm{g}, \mathrm{h}}$, SEBASTIEN DUJARDIN ${ }^{\mathrm{g}, \mathrm{h}}$, CATHERINE LINARD $^{\mathrm{g}, \mathrm{h}}$, TIM NAWROT $^{\mathrm{e}, \mathrm{i}}$, AN VAN NIEUWENHUYSE ${ }^{\mathrm{i}, \mathrm{j}}$, JEAN-MARIE AERTS ${ }^{\mathrm{b}}$, JOS VAN ORSHOVEN ${ }^{\mathrm{a}}$, BEN SOMERS $^{\mathrm{a}}$
\end{abstract}

${ }^{a}$ Division Forest, Nature and Landscape, Department Earth and Environmental Sciences, KU Leuven, Celestijnenlaan 200E-2411, BE-3001 Leuven, Belgium

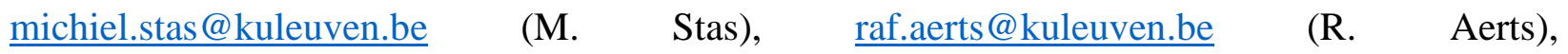
jos.vanorshoven@kuleuven.be (J. Van Orshoven), ben.somers@kuleuven.be (B. Somers)

${ }^{\mathrm{b}}$ Measure, Model \& Manage Bioresponses (M3-BIORES), Division Animal and Human Health Engineering, Department of Biosystems (BIOSYST), KU Leuven, Kasteelpark Arenberg 30-2472, B-3001 Leuven, Belgium

michiel.stas@kuleuven.be (M. Stas), jean-marie.aerts@kuleuven.be (J.-M. Aerts)

${ }^{\mathrm{c}}$ Risk and Health Impact Assessment, Sciensano (Belgian Institute of Health), J. Wytsmanstraat 14, B-1050 Brussels, Belgium

raf.aerts@sciensano.be (R. Aerts)

${ }^{\mathrm{d}}$ Division Ecology, Evolution and Biodiversity Conservation, KU Leuven, Kasteelpark Arenberg 31-3245, BE-3001 Leuven, Belgium

raf.aerts@kuleuven.be (R. Aerts)

${ }^{e}$ Center for Environmental Sciences, Hasselt University, Campus Diepenbeek, Agoralaan Gebouw D, B-3590 Hasselt, Belgium

raf.aerts@uhasselt.be (R. Aerts), tim.nawrot@uhasselt.be (T. Nawrot)

${ }^{\mathrm{f}}$ Mycology and Aerobiology, Sciensano (Belgian Institute of Health), J. Wytsmanstraat 14, B-1050 Brussels, Belgium

raf.aerts@sciensano.be (R. Aerts), marijke.hendrickx@sciensano.be (M. Hendrickx), 'Department of Geography, University of Namur, Rue de Bruxelles 61, B-5000 Namur, Belgium nicolas.dendoncker@unamur.be (N. Dendoncker), sebastien.dujardin@unamur.be (S. Dujardin), catherine.linard@unamur.be (C. Linard) 
hInstitute for Life, Earth and Environment (ILEE), University of Namur, Rue de Bruxelles 61, B5000 Namur, Belgium

nicolas.dendoncker@unamur.be (N. Dendoncker), sebastien.dujardin@unamur.be (S. Dujardin), catherine.linard@unamur.be (C. Linard)

${ }^{i}$ Centre Environment and Health, Department of Public Health and Primary Care, KU Leuven, Kapucijnenvoer 35 blok d box 7001, B-3000 Leuven, Belgium

tim.nawrot@kuleuven.be (T. Nawrot), an.vannieuwenhuyse@kuleuven.be (A. Van Nieuwenhuyse)

jDepartment of Health Protection, Laboratoire national de santé (LNS), 1, Rue Louis Rech, L-3555 Dudelange, Luxembourg

an.vannieuwenhuyse@lns.etat.lu (A. Van Nieuwenhuyse)

* Corresponding author: Michiel Stas

michiel.stas@kuleuven.be

Celestijnenlaan $200 \mathrm{E}$ - bus 2411; 3001 Heverlee; Belgium +3216320775 
Graphical Abstract

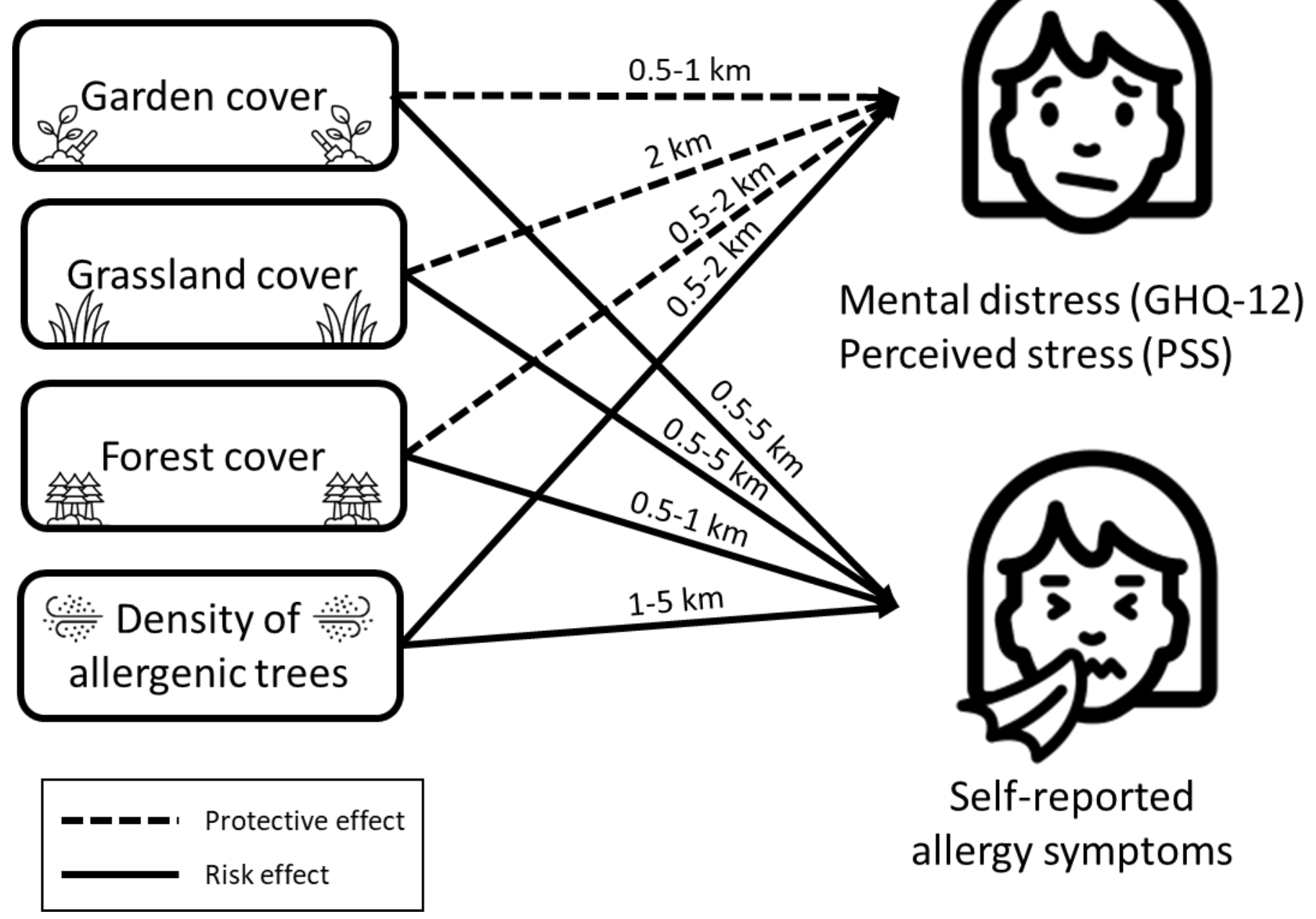




\section{Highlights}

- We studied residential green space exposure of 157 adults with tree pollen allergy.

- $\quad$ Residential green space was associated with reduced mental distress and perceived stress.

- $\quad$ Allergenic tree species within $2 \mathrm{~km}$ distance contributed to mental distress.

- $\quad$ Residential green space exposure was associated with more severe allergy symptoms.

- Green space had mixed health effects during the pollination season. 


\begin{abstract}
Background: Exposure to green space has been associated with positive mental and physical health outcomes. Nevertheless, green space can also act as a source of aeroallergens and exacerbate allergic disease and related mental distress. We examined impacts of exposure to residential green space on respiratory health and well-being in a cohort of adults sensitized to tree pollen allergens.

Methods: In a panel of 157 tree pollen allergy patients in Belgium we analyzed average allergy symptom scores, average mood scores, distress (GHQ-12) and perceived stress (PSS). Generalized linear models were used to investigate associations between health outcomes and garden cover, grassland cover, forest cover and density of trees of the allergenic Alnus, Betula and Corylus genera in forests within a 1,2 and $5 \mathrm{~km}$ distance from the residence. Models were adjusted for sex, age, BMI, allergy medication use, chronic respiratory disease, smoking behavior, education level, physical activity and perceived presence of allergenic trees.

Results: We observed inverse associations between residential garden cover within $1 \mathrm{~km}$ distance and perceived stress (PSS) (unadjusted $\beta=-0.020 ; 95 \%$ CI $[-0.031 ;-0.008]$ ) and between forest cover within $1 \mathrm{~km}$ and distress (GHQ-12) (-0.048 [-0.085; -0.011]). Higher densities of allergenic trees in forests within $2 \mathrm{~km}$ distance were associated with higher PSS (0.003 [0.000 - 0.006]) and GHQ-12 scores $(0.020$ [0.014; 0.027]). Residential green space variables within $1 \mathrm{~km}$ distance were associated with higher symptom scores: garden cover $\beta=0.013[0.007 ; 0.018]$, grassland $\operatorname{cover} \beta=0.020$ [0.014;0.026], forest cover $\beta=0.016$ [0.010;0.021], density of allergenic trees in forests $\beta=0.005[0.001 ; 0.009]$. The parameter estimates became smaller at larger scales and remained significant in the fully adjusted models.

Conclusion: Green space is associated with more symptoms but lower distress and allergenic trees in forests are associated with higher distress Residential green space has mixed health effects in tree pollen allergy patients.
\end{abstract}


1 Residential green space types, allergy symptoms and mental health in a cohort

2 of tree pollen allergy patients

3 1. Introduction

4 Exposure to green space is often found to improve human physical and mental health (Aerts et al.,

5 2018; Fong et al., 2018; Twohig-Bennett and Jones, 2018). Exposure and proximity to green space

6 has been associated with higher birth weights (Agay-Shay et al., 2014), lower blood pressure

7 (Grazuleviciene et al., 2014), reduced risk in diabetes (Dalton et al., 2016), lower risks of prostate

8 cancer (Demoury et al., 2017), lower risk of psychiatric disorders (Engemann et al., 2019) and

9 better mental health (Bratman et al., 2019). These studies often target vulnerable population groups

10 such as pregnant women (Grazuleviciene et al., 2014), elderly people (Dalton et al., 2016), and

11 children (Engemann et al., 2018; Rufo et al., 2019). So far, tree pollen allergy patients, who may

12 experience ecosystem disservices from exposure to green space, are an understudied group.

13 Sensitization to common aeroallergens is expected to increase in the following decades due to

14 urbanization, air pollution, and climate change (D’Amato et al., 2016; Lake et al., 2017). To

15 improve air quality and mitigate climate change effects, such as urban heat, urban planners

16 promote the creation of additional green space and urban forests (Livesley et al., 2016). While tree

17 planting in cities might contribute to better respiratory health through improvement of air quality

18 and thermal comfort, some tree species may also emit aeroallergens and trigger allergies and

19 asthma (Eisenman et al., 2019).

20 Recently a considerable number of studies on residential green space exposure and respiratory

21 health in children has emerged. These studies reported that residential proximity to green space

22 and residential greenness is associated with a reduced risk of bronchitis and wheezing (Tischer et 
23 al., 2017). Other studies, however, find that children living with more green space near their home

24 suffer more from wheezing and have an increased risk of allergic rhinitis (Parmes et al., 2020) and

25 asthma (Andrusaityte et al., 2016). Other studies have documented that higher levels of grassland

26 cover around the residence of children were associated with an increased risk of grass pollen

27 sensitization in children (Gernes et al., 2019) and prescribed asthma medication sales (Aerts et al.

28 2020a). From these studies it is clear that green space in children's neighborhoods has an effect on

29 their respiratory health. Whether this is a protective factor or a risk might be determined by

30 confounders such as biodiversity, environmental microbiome, or behavior (Rufo et al., 2019).

31 Only a limited number of studies on green space and respiratory health in adults are available. A

32 first large scale study in England found that the presence of more tree cover, gardens, and green

33 space in residential areas was associated with fewer asthma hospitalizations (Alcock et al., 2017).

34 Ulmer et al. (2016) found that urban tree cover was associated with less diagnoses of current

35 asthma. In a previous study in Northern Belgium, we found that adults sensitized to tree pollen

36 experience mental health benefits from residential exposure to green, despite their tree pollen

37 allergy (Aerts et al., 2020b). However, the perceived presence of allergenic tree species was found

38 to be associated with higher mental distress (Aerts et al., 2020b). The aim of this study was to

39 examine whether different types of residential green space cover, i.e. forests, gardens, and

40 grasslands, and the objectively measured quantity of allergenic tree species in forests near the

41 residence have impacts on allergy symptoms and mental health of allergy patients sensitized to

42 hazel, alder and/or birch pollen. 


\section{2. Methods}

45

46

47 Commission of the KU Leuven University Hospital (Belgian registration number

\subsection{Study design and population}

48

57 Of the 225 persons interested in participating $189(84 \%)$ were included in the RespirIT study.

58 Ultimately 32 participants dropped out and thus anonymized data from 157 (70\%) participants

59 were used in this cross-sectional study (Figure 1). The participants used the mobile app on 8123

60 person-days of which 4714 were symptom-days used in the analysis. A symptom-day corresponds

61 to a person-day on which the participant reported pollen allergy symptoms. The spatial distribution

62 of the residences of the participants are visualized in the supplementary material (Figure S1). 


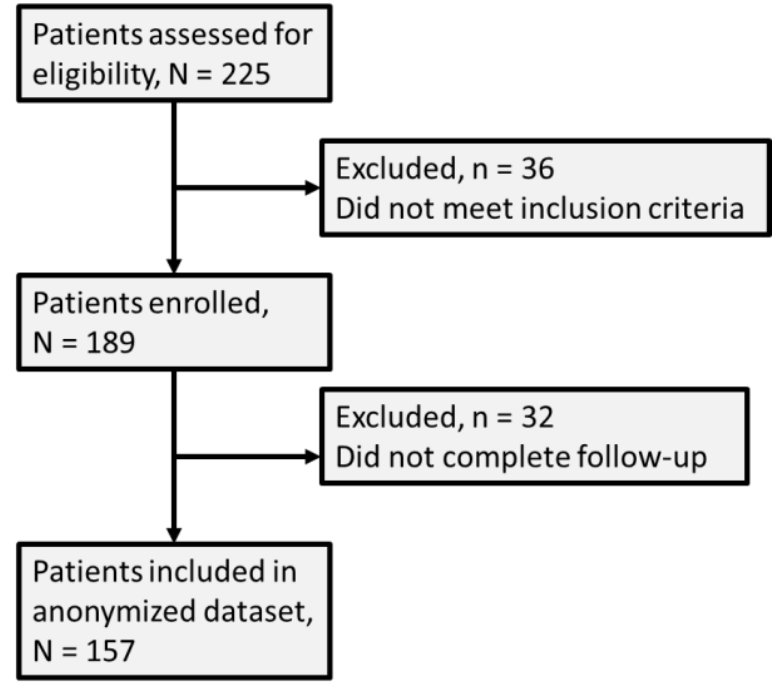

64 Figure 1: Flow diagram of the selection process for the tree pollen allergy patients suitable for 65 analysis.

\subsection{Definition of the outcome variables}

67 Participants reported their mood and allergy symptoms daily in the diary of the Dutch or French

68 language smartphone application specifically created for the RespirIT study (RespirIT app for 69 Android OS for mobile phones, BioRICS NV, Belgium). The user-manual encouraged the 70 participants to fill in the diary at the end of every day as to have an idea of the overall mood and 71 symptoms during the past day. In case the participants experienced symptoms that were not due to 72 a regular cold or a flue they were asked to record these at the end of the day in the diary of the 73 RespirIT app. The diary asked the question 'What symptoms are bothering you today and to what 74 degree?', followed by a list of eleven symptoms related to seasonal pollen allergy: wheezing,

75 dyspnea, coughing, sneezing, runny or stuffy nose, itching, fatigue, headache, bad sleep, difficulty 76 concentrating, and irritation of the eyes. Under every symptom the participant could move a slider 77 from 0 (never) to 4 (always). The daily symptom score was calculated by summing the individual 78 values for the eleven symptoms resulting in a scale from 0 to 44,0 corresponding to no allergy 
79 symptoms. We calculated the average symptom score on symptom days (AvgSy) multiplied by 10 80 and truncated to no decimals.

81 Daily mood was assessed on the same symptom days with one question 'How did you feel today?'

82 and scored on a five-point rating scale represented by minimalist smileys (Figure S2). A score

83 from 1 to 5 was assigned to the moods: 1) poor, 2) fair, 3) neutral, 4) good 5) excellent. We

84 calculated the average mood score on symptom days (AvgMo) multiplied by 10 and truncated to

85 no decimals.

86 Two validated questionnaires were used to quantify mental health outcomes during the tree pollen

87 season. The Dutch and French version of the standardized questionnaires were integrated in the

88 follow-up questionnaire sent out to the participants during the pollen season. First, the 12-item

89 General Health Questionnaire (GHQ-12) is a shorter version of the fully detailed 60-item General

90 Health Questionnaire (https://www.gl-assessment.co.uk/products/general-health-questionnaire-

$91 \mathrm{ghq} /$ ). In the GHQ respondents were asked how their mental state during the past month differed

92 from the usual state. The GHQ is sensitive to short-term psychiatric disorders and can be

93 interpreted as a measure for psychological distress. To score the GHQ-12 we used the standard

94 bimodal scoring method (0-0-1-1) resulting in a scale range of $0-12$, a higher score meaning more

95 distress. Second, the Perceived Stress Scale (PSS) is a widely used validated questionnaire to 96 measure the perception of stress over the past month

97 (http://www.mindgarden.com/documents/PerceivedStressScale.pdf). The scale includes items

98 about current levels of stress as well as items on stressful times during the past month. Questions

99 are scored on a five-point rating scale (0-4). Four of the questions, however, are formulated in a

100 positive way and needed to be scored in reverse. After summation of the scores the scale ranges

101 from 0 to 40 , where 0 is best. 


\subsection{Definition of potential predictors}

103 Residential green space was objectively quantified from geodatasets for a $0.5,1,2$ and $5 \mathrm{~km}$ radius 104 around each of the 157 residences. Using topological overlay between the corresponding circular 105 zones and the Top10 Vector land cover geodataset for Belgium ("Soil cover and vegetation" 106 dataset, version 1.1 2011, National Geographic Institute, equivalent scale level of 1:10,000), the 107 cumulative cover $\left(\mathrm{m}^{2}\right)$ of three green space types (gardens, grassland and forest) was determined 108 for the three radii. Gardens are included as a unique land cover type in the dataset. Grassland cover 109 was calculated as the sum of permanent grassland or hay meadow and lawns. Forest cover was 110 determined as the sum of all five forest-related land cover types in the geodataset: 1) coniferous 111 forests, 2) mixed forests dominated by conifer species, 3) mixed forests, 4) mixed forests 112 dominated by deciduous species, 5) deciduous forests. Garden, grassland and forest covers within 113 each radius were then expressed in 10 ha units.

114 The Belgian forest inventory uses a regular grid of $0.5 \times 1 \mathrm{~km}$ covering the entire area of Belgium.

115 The grid points that occur in forested areas were visited by experienced surveyors who record the 116 species type and circumference at $1.30 \mathrm{~m}$ above ground level of trees and woody vegetation in an $11718 \mathrm{~m}$ radius around the point (Westra et al., 2015). From the circumference and the plot area we 118 were able to calculate the basal area $\left(\mathrm{m}^{2} / \mathrm{ha}\right)$ of the three main allergenic taxa Alnus (alder), Betula 119 (birch), and Corylus (hazel) from the Belgian forest inventory. The total basal area of the allergenic 120 trees can be interpreted as the density of allergenic trees in the forest. 


\subsection{Definition of potential confounders}

125 We included the participant's sex and age as sociodemographic characteristics. Next, we included

126 three indicators of physical fitness: body mass index (BMI), smoking behaviour (yes/no), and 127 physical activity (at least $1 \times /$ week 20 min of activity vs. less). Education level (higher education 128 vs. no higher education) was included as indicator of socio-economic status of the participants. 129 Higher education is defined as having obtained an academic degree through a tertiary education. 130 Regarding the health status of the participants we included two items: medication use 131 (antihistamines and/or corticosteroids: yes/no) and chronic disease (asthma and/or chronic 132 respiratory disease: yes/no). Participants were asked to report whether hazel, alder and/or birch 133 trees were present or absent in close proximity to their residence. The objective presence of these 134 allergenic trees was not verified (outside forested areas). Therefore, the reported presence of 135 allergenic trees is interpreted as perceived presence (Aerts et al., 2020b).

\subsection{Statistical analyses}

138 Generalized linear models based on the Poisson probability distribution for count data with log139 link function were used to estimate the effects of residential green space exposure on allergy 140 symptoms and mental health of participants. The unadjusted models included only objective green 141 space predictors. In the fully adjusted model all the confounders were included at once. To test 142 whether having more severe allergy symptoms may reduce a potential positive effect of exposure 143 to forests on distress, we included allergy symptoms as additional explanatory variables in models 144 for mental health. We calculated both unadjusted and confounder-adjusted estimates and their $95 \%$ 145 Wald confidence intervals. Model performance was evaluated using Akaike's Information 
146 Criterion (AIC). Models were created and evaluated using IBM SPSS (Version 26) predictive 147 analytics software.

149 3. Results

$150 \quad 3.1$ Population characteristics

151 The summary of the study population characteristics is given in Table 1. Our cohort consisted of 15295 women $(60.5 \%)$ and 62 men (39.5\%). All participants were adults aged between 21 and 67 153 years (median age 39, IQR 16). Over half of the patients had a normal body weight (58.6\% normal 154 BMI; median BMI 23.5 $\mathrm{kg} \mathrm{m}^{-2}$, IQR 5.5). The majority of the patients were non-smokers (96.2\%), 155 were physically active ( $\geq 20 . \mathrm{min}$ active/week: $91.1 \%)$ and had a higher education level (91.1\%). 156 Almost all of the allergy patients took medication (93.3\%), with 52.9\% of the allergy patients using 157 antihistamines, $7.0 \%$ using corticosteroids, and $34.4 \%$ taking a combination of both. Some patients 158 suffered from other chronic respiratory health issues besides pollen allergy, mostly asthma $159(28.6 \%)$.

160 The most prevalent green space types present around the residency was gardens, followed by 161 grasslands, and then forests (Table 1 and Figure 2). As the distance from the residence increased 162 the area fraction of gardens decreased, while the area fraction of grassland and forest increased. 163 The density of allergenic trees in the forest increased with the increasing forest area fraction. 


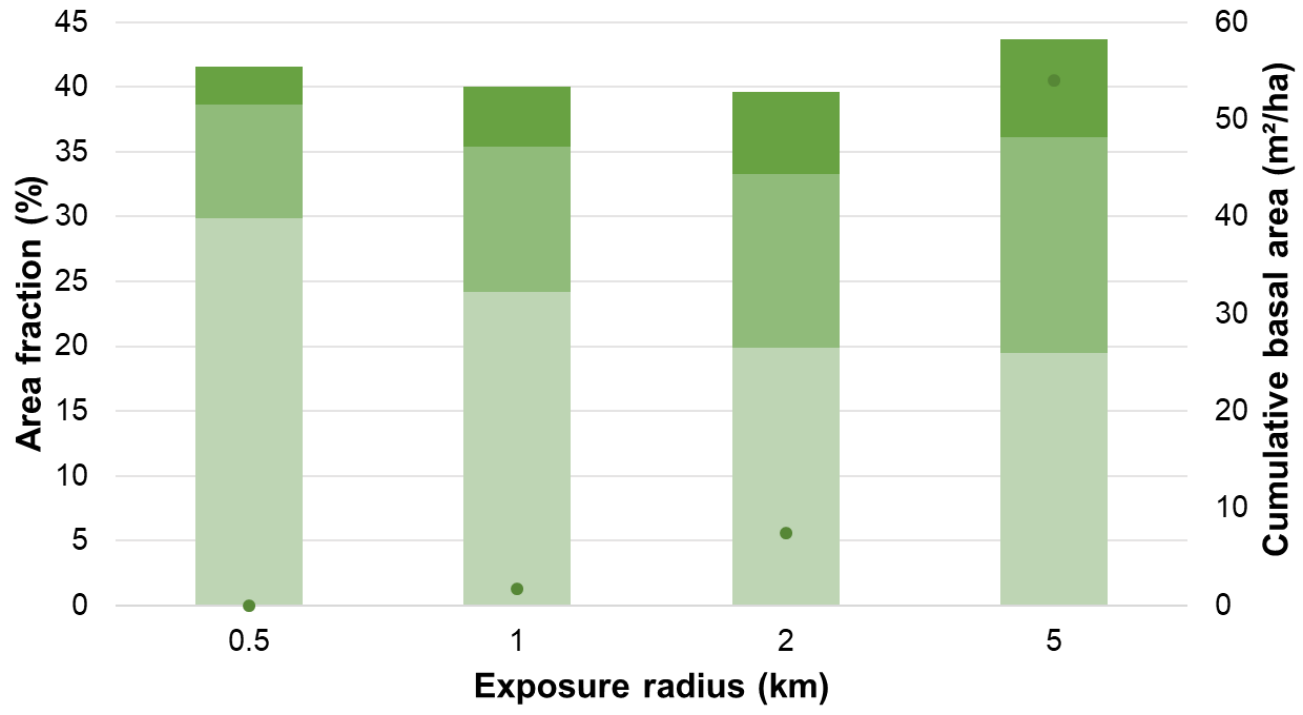

$\square$ Garden $\square$ Grassland $\square$ Forest $\bullet$ Allergenic trees

165 Figure 2: A stacked bar plot presenting area fractions of residential green space (garden cover, grassland 166 cover and forest cover) within the four exposure radii $(0.5,1,2$ and $5 \mathrm{~km})$ studied. The cumulative density 167 of allergenic trees within the entire forest area fraction is presented as a dot.

168 Table 1: Study population characteristics, potential predictors and mental and respiratory health 169 outcomes $(n=157)$.

\begin{tabular}{|c|l|}
\hline Characteristic & $\begin{array}{l}\mathbf{n}(\boldsymbol{\%}), \text { or mean }(\mathbf{S D}), \text { and median } \\
\left(\mathbf{2 5}^{\text {th }}-\mathbf{7 5}^{\text {th }} \text { percentiles }\right)\end{array}$ \\
\hline Sex female & $95(60.5 \%)$ \\
\hline male & $62(39.5 \%)$ \\
\hline Age in years & $\begin{array}{l}40.2(9.8) \\
39.0(32.0-48.0)\end{array}$ \\
\hline BMI & $24.4(4.4)$ \\
& $23.5(21.2-26.7)$ \\
\hline BMI classes & $6(3,8 \%)$ \\
\hline underweight $(<18.5)$ & \\
\hline
\end{tabular}




\begin{tabular}{|c|c|}
\hline normal $(18.5-24.9)$ & $92(58,6 \%)$ \\
\hline overweight (25.0-29.9) & $36(23.0 \%)$ \\
\hline obesity $(\geq 30)$ & $23(14,6 \%)$ \\
\hline \multicolumn{2}{|l|}{ Smoking behavior } \\
\hline non-smoker & $151(96.2 \%)$ \\
\hline smoker & $6(3.8 \%)$ \\
\hline \multicolumn{2}{|l|}{ Physical activity (20 min or more) } \\
\hline$<1 \times 20^{\prime} /$ week & $14(8.9 \%)$ \\
\hline$\geq 1 \times 20 \% /$ week & $143(91.1 \%)$ \\
\hline \multicolumn{2}{|l|}{ Education level } \\
\hline lower education & $14(8.9 \%)$ \\
\hline higher education & $143(91.1 \%)$ \\
\hline \multicolumn{2}{|l|}{ Allergy medication use } \\
\hline antihistamines & $83(52.9 \%)$ \\
\hline corticosteroids & $11(7.0 \%)$ \\
\hline both & $54(34.4 \%)$ \\
\hline none & $9(5.7 \%)$ \\
\hline \multicolumn{2}{|l|}{ Chronic respiratory problems } \\
\hline asthma & $45(28.6 \%)$ \\
\hline chronic respiratory disease & $0(0.0 \%)$ \\
\hline both & $4(2.6 \%)$ \\
\hline none & $108(68.8 \%)$ \\
\hline \multicolumn{2}{|l|}{ Perceived presence of allergenic tree species } \\
\hline $\begin{array}{l}\text { Alnus, Betula, and/or corylus present near } \\
\text { residence }\end{array}$ & $123(78.3 \%)$ \\
\hline not present near residence & $34(21.7 \%)$ \\
\hline \multicolumn{2}{|l|}{ Garden cover (ha) } \\
\hline $0.5 \mathrm{~km}$ radius & $\begin{array}{l}23.0(11.4) \\
23.6(15.4-30.2)\end{array}$ \\
\hline $1 \mathrm{~km}$ radius & $80.6(37.5)$ \\
\hline
\end{tabular}




\begin{tabular}{|c|c|}
\hline & $75.9(56.2-106.2)$ \\
\hline $2 \mathrm{~km}$ radius & $\begin{array}{l}271.5(118.7) \\
252.1(190.9-353.8)\end{array}$ \\
\hline $5 \mathrm{~km}$ radius & $\begin{array}{l}1485.0(424.8) \\
1532.5(1276.4-1793.9)\end{array}$ \\
\hline Grassland cover (ha) & \\
\hline $0.5 \mathrm{~km}$ radius & $\begin{array}{l}9.3(8.5) \\
6.9(3.7-14.9)\end{array}$ \\
\hline $1 \mathrm{~km}$ radius & $\begin{array}{l}45.0(35.6) \\
35.1(20.9-62.1)\end{array}$ \\
\hline $2 \mathrm{~km}$ radius & $\begin{array}{l}195.9(125.1) \\
169.2(99.6-252.8)\end{array}$ \\
\hline $5 \mathrm{~km}$ radius & $\begin{array}{l}1355.3(651.6) \\
1304.2(819.7-1755.6)\end{array}$ \\
\hline \multicolumn{2}{|l|}{ Forest cover (ha) } \\
\hline $0.5 \mathrm{~km}$ radius & $\begin{array}{l}5.9(10.2) \\
2.4(0.5-5.9)\end{array}$ \\
\hline $1 \mathrm{~km}$ radius & $\begin{array}{l}28.2(39.5) \\
14.4(6.2-31.4)\end{array}$ \\
\hline $2 \mathrm{~km}$ radius & $\begin{array}{l}132.1(141.4) \\
79.5(35.2-187.4)\end{array}$ \\
\hline $5 \mathrm{~km}$ radius & $\begin{array}{l}1055.7(904.6) \\
593.5(346.4-1604.6)\end{array}$ \\
\hline $\begin{array}{l}\text { Density of Alnus, Betula and Corylus in forest plots } \\
\left(\mathrm{m}^{2} / \mathrm{ha}\right)\end{array}$ & \\
\hline $0.5 \mathrm{~km}$ radius & $\begin{array}{l}0.4(2.4) \\
0.0(0.0-0.0)\end{array}$ \\
\hline $1 \mathrm{~km}$ radius & $\begin{array}{l}1.7(5.7) \\
0.0(0.0-0.0)\end{array}$ \\
\hline $2 \mathrm{~km}$ radius & $7.5(15.3)$ \\
\hline
\end{tabular}




\begin{tabular}{|c|l|}
\hline & $0.0(0.0-7.5)$ \\
\hline 5 km radius & $54.0(74.2)$ \\
& $32.2(7.3-55.6)$ \\
\hline Mental health endpoints & \\
\hline Distress (GHQ-12) & $2.2(2.8)$ \\
& $1.0(0.0-3.0)$ \\
\hline Perceived stress scale (PSS) & $13.6(6.7)$ \\
& $14.0(9.0-18.0)$ \\
\hline Average daily mood & $37.9(5.5)$ \\
& $38.0(36.0-40.0)$ \\
\hline Respiratory health endpoint & \\
\hline Average symptom score & $56.4(38.1)$ \\
& $48.0(31.0-72.0)$ \\
\hline
\end{tabular}

\subsection{Predictors of mental health and allergy symptoms}

\subsubsection{Predictors of mental health}

173 The parameter estimates $[\beta(95 \% \mathrm{CI})]$ of the unadjusted associations between possible predictors 174 and mental health (Average Mood, GHQ-12, PSS) are presented in Table S1 and Figure 3. Distress 175 (GHQ-12) was inversely associated with forest cover within 0.5, 1 and $2 \mathrm{~km}$ distance [0.5 km: $1760.274(-0.443 ;-0.104)$ and $1 \mathrm{~km}:-0.048(-0.085 ;-0.011)$ and $2 \mathrm{~km}:-0.023(-0.034 ;-0.012)]$. 177 Perceived stress (PSS) was inversely associated with garden cover within 0.5 and $1 \mathrm{~km}$ distance $178 \quad[0.5 \mathrm{~km}:-0.065(-0.105 ;-0.026)$ and $1 \mathrm{~km}:-0.020(-0.031 ;-0.008)]$ and grassland cover within $1792 \mathrm{~km}$ distance $[-0.005(-0.009 ;-0.001)]$. Both distress and perceived stress were associated with 180 the density of allergenic trees (Alnus, Betula and Corylus) within 0.5 and $2 \mathrm{~km}$ distance [distress: $1810.5 \mathrm{~km}: 0.037(0.001-0.073)$ and $2 \mathrm{~km}: 0.020(0.014 ; 0.027)$; perceived stress: $2 \mathrm{~km}: 0.003(0.000$;

182 0.006)]. Average daily mood on symptom days was not associated with measures of exposure to 
183

184

185

186

187

188

189

190

191

192

193

194

195

196

197

198

199

200

201

202

203

204 green assessed in this study. In the set of green space indicators calculated for a $5 \mathrm{~km}$ radius, only perceived stress was inversely associated with density of allergenic trees $[-0.001(-0.001 ; 0.000)]$ and with forest cover $[0.001 ;(0.000 ; 0.001)]$.

Fully adjusted beta-coefficients and 95\% confidence intervals are presented in Table S2 and Figure 4 (Figure S2 includes adjustment variables). Mental distress remained inversely associated with exposure to forest within $0.5,1$, and $2 \mathrm{~km}$ distance $[0.5 \mathrm{~km}:-0.048(-0.086 ;-0.011)$ and $1 \mathrm{~km}:-$ $0.048(-0.086 ;-0.011)$ and $2 \mathrm{~km}:-0.020(-0.030 ;-0.009)]$. Distress remained associated with the density of allergenic trees within $2 \mathrm{~km}$ distance (but not $0.5 \mathrm{~km})[0.021(0.014 ; 0.028)]$. There were no significant associations between distress and objective exposure to green types within 5 $\mathrm{km}$ distance. After full adjustment, perceived stress remained inversely associated with objective exposure to gardens within 0.5 and $1 \mathrm{~km}$ distance $[0.5 \mathrm{~km}:-0.025(-0.037 ;-0.012)$ and $1 \mathrm{~km}:-$ $0.025(-0.037 ;-0.012)]$, and was inversely associated with density of allergenic trees within $1 \mathrm{~km}$ $[-0.011(-0.020 ;-0.001)]$. Perceived stress was inversely associated with residential exposure to grassland cover within a 2 and a $5 \mathrm{~km}$ distance $[2 \mathrm{~km}:-0.006(-0.009 ; 0.002)$ and $5 \mathrm{~km}:-0.001(-$ 0.002; 0.000)]. No significant associations were found between average daily mood on symptom days and any of the potential predictors.

At all the spatial scales average symptom score (AvgSy) was associated with the mental health outcomes (Figure 5 and Table S3). The associations with the greenspace remained unchanged for the response variable GHQ12 when including AvgSy as a condounder. For the model outcome PSS the inclusion of AvgSy modified the effect of the density of allergenic trees in forests within a $0.5[-0,069(-0,112 ;-0,026)]$ and $1 \mathrm{~km}[-0,010(-0,019 ;-0,001)]$ exposure radius. 


\subsubsection{Predictors of allergy symptoms}

206 The parameter estimates $[\beta(95 \% \mathrm{CI})]$ of the unadjusted associations between predictors of green 207 space type in the residence with the average symptom score (AvgSy) are presented in Figure 3 and 208 Table S1. Symptom scores (higher AvgSy) were associated with exposure to garden cover [0.5 $209 \mathrm{~km}: 0.051(0.032 ; 0.071)$ and $1 \mathrm{~km}: 0.013(0.007 ; 0.018)$ and $2 \mathrm{~km}: 0.005(0.003 ; 0.006)]$, grassland 210 cover [0.5 km: $0.086(0.062 ; 0.110)$ and $1 \mathrm{~km}: 0.020(0.014 ; 0.026)$ and $2 \mathrm{~km}: 0.006(0.005 ; 0.008)$ 211 and $5 \mathrm{~km}: 0.001(0.001 ; 0.002)]$, forest cover $[0.5 \mathrm{~km}: 0.049(0.027 ; 0.070)$ and $1 \mathrm{km:} 0.016(0.010$

$2120.021)]$ and density of Alnus, Betula and Corylus trees in forests [1 km: $0.005(0.001 ; 0.009)$ and $2132 \mathrm{~km}: 0.007(0.007 ; 0.008)$ and $5 \mathrm{~km}: 0.001(0.001 ; 0.002)]$. The parameter estimates decreased 214 with increasing radius around the residence.

215 Fully adjusted beta-coefficients and 95\% confidence intervals for associations of respiratory health 216 outcomes (AvgSy) with all predictors are presented in Figure 3 and Table S2 (Figure S2 includes 217 adjustment variables). The associations between allergy symptoms and green space types of the 218 fully adjusted model are the same as for the unadjusted model. Symptom scores (AvgSy) were 219 associated with exposure to garden cover [0.5 km: $0.008(0.002 ; 0.014)$ and $1 \mathrm{~km}: 0.008(0.002$; $220 \quad 0.014)$ and $2 \mathrm{~km}: 0.004(0.002 ; 0.006)]$, grassland cover [0.5 km: $0.013(0.006 ; 0.019)$ and $1 \mathrm{~km}$ : $2210.013(0.006 ; 0.019)$ and $2 \mathrm{~km}: 0.005(0.003 ; 0.007)$ and $5 \mathrm{~km}: 0.001(0.001 ; 0.002)]$, forest cover $222 \quad[0.5 \mathrm{~km}: 0.017(0.011 ; 0.022)$ and $1 \mathrm{~km}: 0.017(0.011 ; 0.022)]$ and density of allergenic trees in 223 forests [2 km: $0.005(0.004 ; 0.007)$ and $5 \mathrm{~km}: 0.001(0.001 ; 0.001)]$. 


\section{$225 \quad 3.3$ Model performance}

226 Table S4 contains the values of Akaike's information criterion (AIC) used to evaluate and compare

227 the models performance. The lowest AIC was obtained in unadjusted and fully adjusted models

228 for GHQ12 and Average Symptom score that used exposures calculated within $2 \mathrm{~km}$ distance. The

229 unadjusted PSS model performed best at the $0.5 \mathrm{~km}$ radius, while the adjusted PSS model

230 performed best at the $1 \mathrm{~km}$ radius and worst at the $0.5 \mathrm{~km}$ radius. 

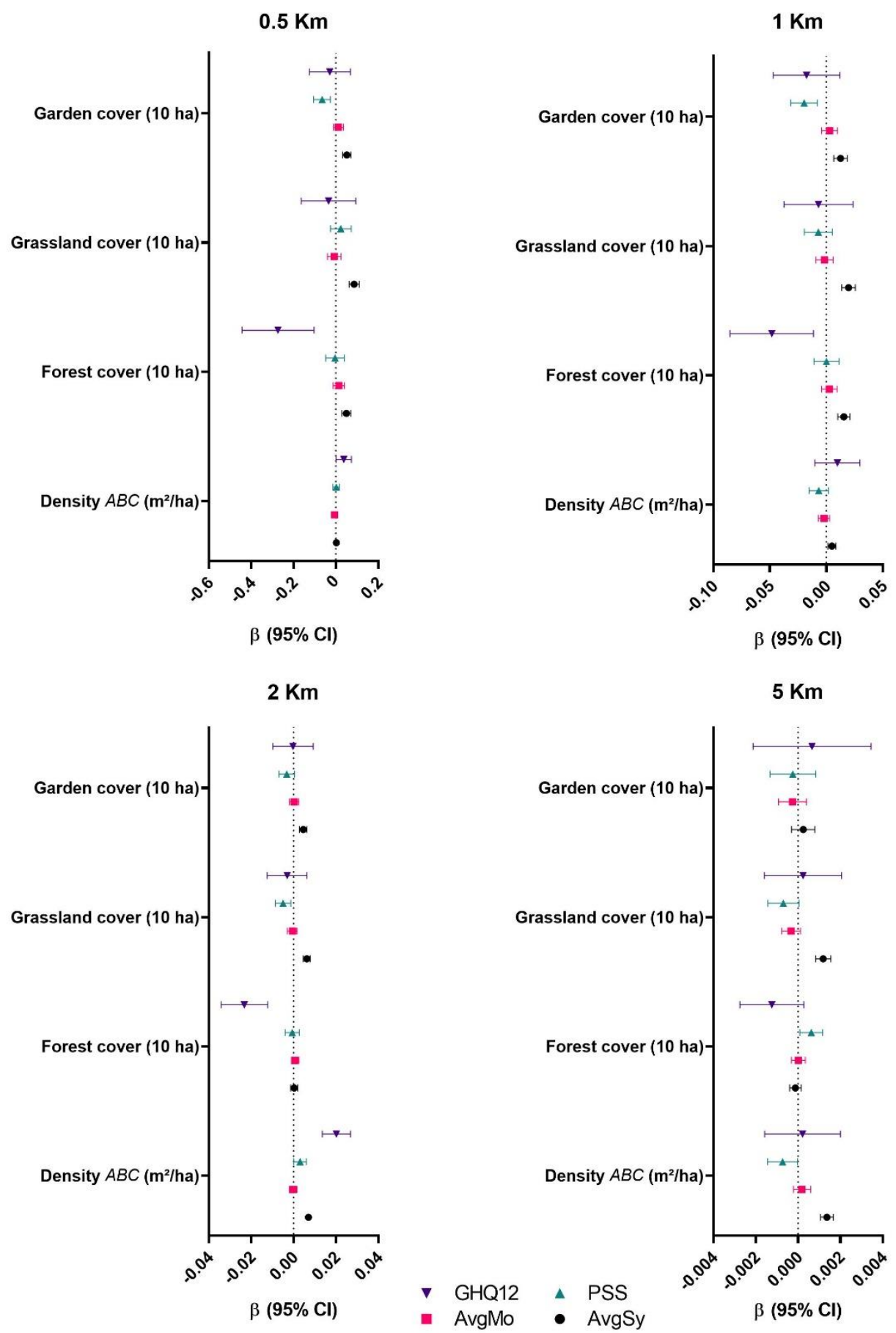

232 Figure 3: Associations (beta-coefficients with 95\% confidence interval limits) between health outcomes and residential green space indicators in a $0.5 \mathrm{~km}, 1 \mathrm{~km}, 2 \mathrm{~km}$ and $5 \mathrm{~km}$ radius around the residence in a cohort of 157 tree pollen allergy patients in Belgium. Models were not adjusted for patient background variables. The response variables are the score of the 12-item General Health Questionnaire (GHQ-12), score of the Perceived Stress Scale (PSS), average mood score (AvgMo) and average symptom score 237 (AvgSy). 

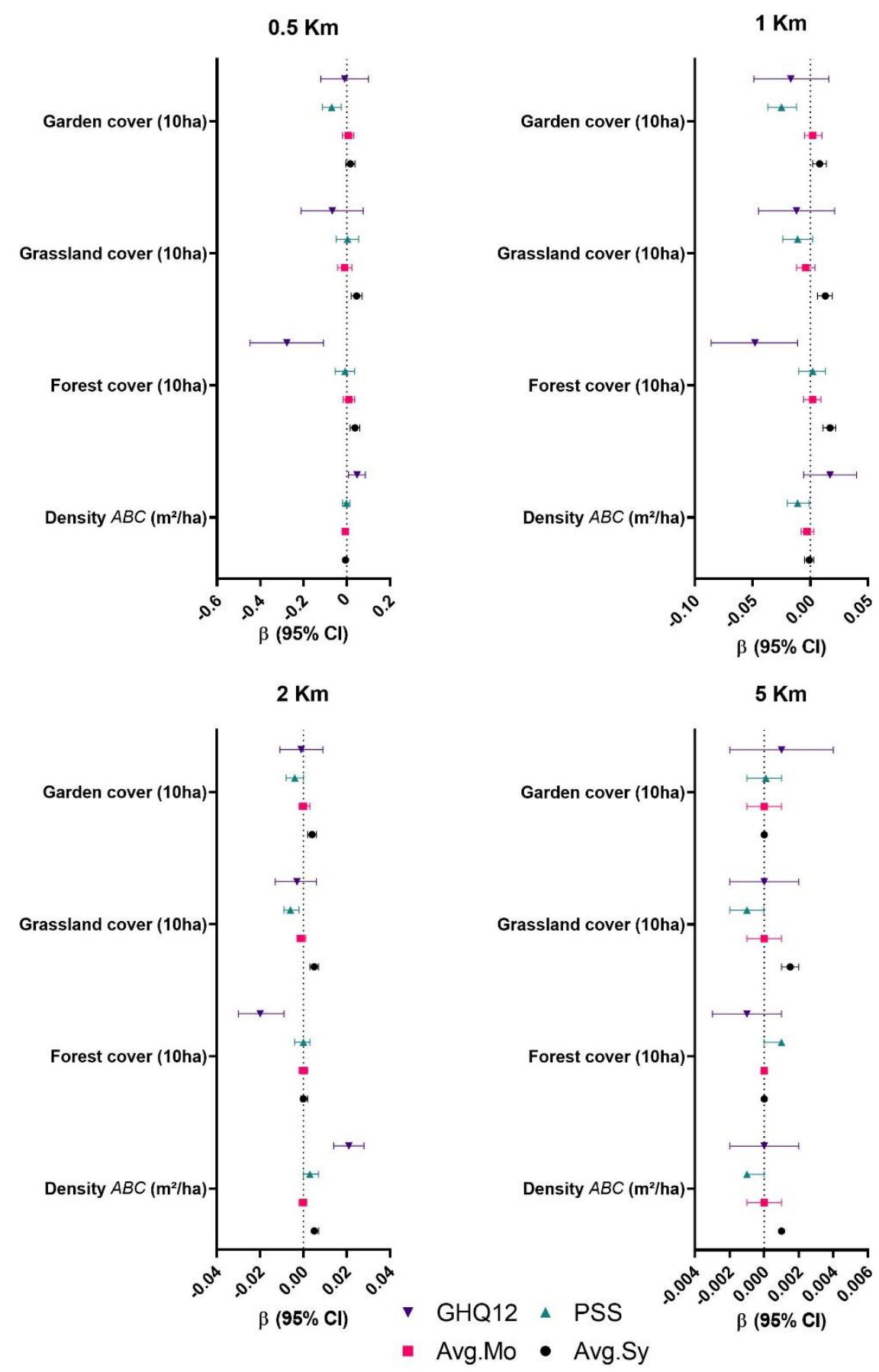

- Avg.Mo • Avg.Sy

Figure 4: Associations (beta-coefficients with 95\% confidence interval limits) between health outcomes and objective residential green space indicators in a $0.5 \mathrm{~km}, 1 \mathrm{~km}, 2 \mathrm{~km}$ and $5 \mathrm{~km}$ radius around the residence in a cohort of 157 tree pollen allergy patients in Belgium. Parameter estimates are adjusted for sex, age, BMI, medication intake, chronic respiratory disease, smoking behavior, higher education, physical activity and perceived presence of allergenic trees. The response variables are the score of the 12-item

244 General Health Questionnaire (GHQ-12), score of the Perceived Stress Scale (PSS), average mood score 245 (Avg.Mo) and average symptom score (Avg.Sy). 

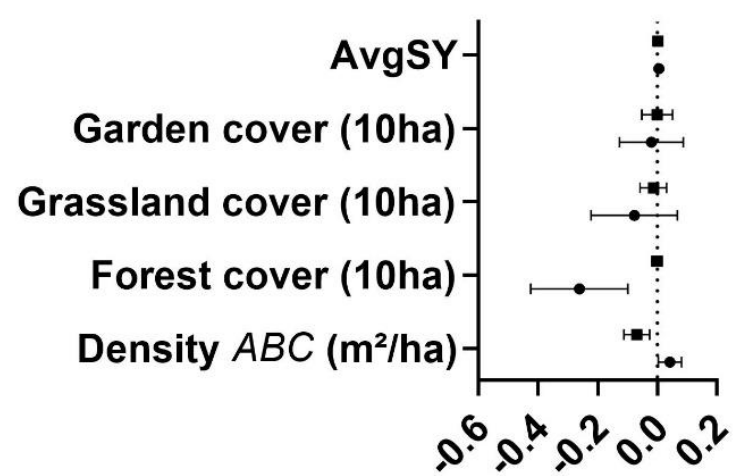

$\beta(95 \% \mathrm{Cl})$

$2 \mathrm{Km}$
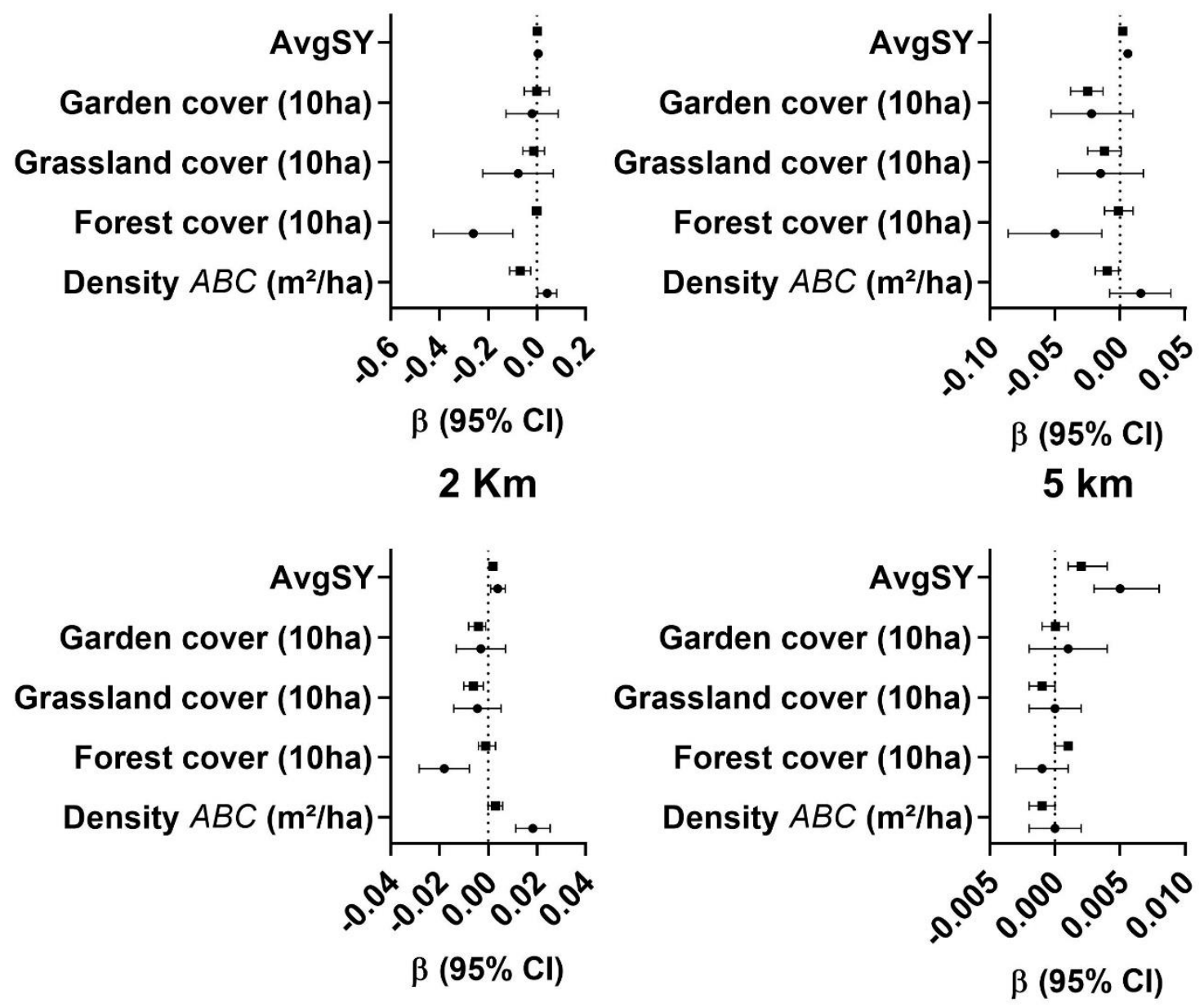

- GHQ12 - PSS

247 Figure 5: Association between exposure to green space and mental health (GHQ12 and PSS) adjusted for

248 all confounders including average allergy symptom severity. Exposure to green space was determined for 249 radii of $0.5 \mathrm{~km}, 1 \mathrm{~km}, 2 \mathrm{~km}$ and $5 \mathrm{~km}$ around the residence in a cohort of 157 tree pollen allergy patients in 250 Belgium. 


\section{Discussion}

\subsection{Key findings}

254 In our cohort of 157 tree pollen allergy patients residing in Belgium, exposure to residential green 255 space (gardens, grasslands and forests) had a protective effect on short-term mental distress (GHQ256 12) and perceived stress (PSS) during the tree pollen season. However, the objective presence of 257 allergenic trees in forests near the residence, in particular within a $2 \mathrm{~km}$ distance, was found to be 258 a risk factor for short-term mental distress and perceived stress. More severe allergy symptoms 259 were associated with worse mental health. Exposure to residential green space was associated with 260 higher allergy symptom scores but did not affect daily mood. We did not find evidence that green 261 space had a mitigating effect on respiratory health complaints of allergy patients during the tree 262 pollen season.

\section{$264 \quad 4.2$ Comparisons with other studies}

Mental well-being. In agreement with other studies we find that residential green is beneficial for

266 mental well-being and contributes to lower perceived stress levels. In the UK, a study with 263

267 respondents found that increased vegetation cover around the residence was associated with better

268 mental health outcomes based on the Depression Anxiety Stress Scale (Cox et al., 2017). Data 269 from 8793 respondents in the Catalonia Health Survey in Spain showed that presence of green 270 space within $300 \mathrm{~m}$ of the residence was associated with better mental health, expressed as GHQ27112 (Triguero-Mas et al., 2015). Data from the British Household Panel Survey, with over 10,000 272 respondents, showed that individuals living in urban areas with more green space reported better 273 mental health, indexed by GHQ-12 (White et al., 2013). A study with 106 adults in disadvantaged 
274 districts in the UK found that inhabitants of neighborhoods with more green space reported lower 275 perceived stress levels (PSS) (Roe et al., 2013).

276 Daily mood. We did not find associations between residential exposure to green space and daily 277 mood. In contrast, a large scale study in the UK running from August 2010 until February 2011 278 did find that their panel of 20,000 users scored their own happiness 1.8-2.7 points higher on a 0279100 scale when in a green or natural environment compared to continuous urban fabric 280 (MacKerron and Mourato, 2013). A study with 155 adolescents in Illinois (USA) found that 281 exposure to an objectively higher concentration of nature was associated with a better overall mood 282 (Profile of Mood States questionnaire; Edition 2 -Youth) (Li et al., 2018). Our results do not 283 confirm the short term effect of green space on daily mood, possibly because the 5-point-scale we 284 used is not sufficiently sensitive and a 0-100 scale (MacKerron and Mourato, 2013) or a 285 standardized questionnaire (Li et al., 2018; Neill et al., 2019) may be needed to find statistically 286 significant results.

287 Mental distress. When exposure to airborne pollen or allergenic trees cannot be avoided during the 288 pollen season, sensitized individuals may experience psychological stress (Aerts et al., 2020b). 289 Our results add the suggestion that the presence of allergenic trees in nearby forests are a risk 290 factor for mental distress of allergy patients although exposure to residential green space is 291 positively associated with mental well-being. We found that allergy symptoms were associated 292 with higher mental distress, which has been reported in previous studies (Oh et al., 2018). The 293 burden of allergic rhinitis has a far-reaching negative impact on the quality of life of adolescents 294 (Blaiss et al., 2018). Trikojat et al. (2017) found that, during the pollen season, depressive 295 symptoms were stronger in allergy patients compared to control persons while no significant 296 difference in depressive symptoms could be found between controls and allergy patients outside 
297 the pollen season (Trikojat et al., 2017). Pollen allergy patients experience mental distress because

298 of their condition and our results show that objective exposure to allergenic trees in forests within

$299 \quad 1-2 \mathrm{~km}$ distance from the residence and self-reported allergy symptoms contribute to increased

300 mental distress.

301 Respiratory health. In a panel of 4000 people in Barcelona (Spain), participants living in a greener

302 neighborhood (defined as characterized by a higher satellite based greenness index (NDVI) within

$303500 \mathrm{~m}$ ) reported better subjective general health ( $\mathrm{Su}$ et al., 2019). A study with 3000 people in the

304 UK, found that people in more urbanized areas experienced lower amounts of nature or green

305 space and reported worse mental and physical health (Cox et al., 2018). While literature provides

306 evidence of general physical health benefits of nature and green space, we found that green space

307 and presence of allergenic trees are risk factors for respiratory health. Recent studies on respiratory

308 health of children revealed that exposure to green space was associated with increased rhinitis

309 (Parmes et al., 2020) and risk of pollen sensitization (Gernes et al., 2019). In a study with 7910

310 adult participants in California (USA), Ulmer et al. (2016) found that neighborhood tree cover was

311 associated with fewer asthma diagnoses. Additionally, in a large study in England green space,

312 gardens and urban trees were associated with less asthma hospitalizations (Alcock et al., 2017).

313 Even though residential green can be associated with better general health (Cox et al., 2018; Su et

314 al., 2019) and respiratory health (Alcock et al., 2017; Ulmer et al., 2016), our results do not support

315 this evidence for pollen allergy patients. We find that higher exposure to residential green space,

316 gardens, forest, and grasslands alike, is associated with more allergy symptoms in pollen allergy

317 sufferers during the pollen season, despite its beneficial effect on mental health. These results are

318 in line with earlier research in Belgium that reported associations between gardens and grasslands

319 and medication sales for childhood asthma (Aerts et al., 2020a) 
Distance effects: The associations between residential green space area and respiratory health and mental well-being become smaller when the considered exposure radii become larger. Additionally, we find different significant associations at different spatial scales. The recent literature review of Labib et al. (2020a) concluded that associations between green and health outcomes are significant at different scales. It is insufficiently known how to quantify green space for health effect studies objectively. Browning and Lee (2017) suggest that buffer sizes of 1 and 2 $\mathrm{km}$ are best to predict health outcomes. While aggregation of landscapes might reduce the effect size when using larger buffer sizes (Labib et al., 2020b). We find that forest cover within $0.5,1$ and $2 \mathrm{~km}$ distance are protective against mental distress. Forest further away $(5 \mathrm{~km})$ did not contribute to lower distress. It is possible that green space does not affect mental health at such distances, but most studies on green space and mental health do not include buffer sizes over 1000 m (Labib et al., 2020a).

Nearby gardens (within a 0.5 and $1 \mathrm{~km}$ distance) were associated with a lower PSS. Nearby garden cover can indicate the presence of a private garden. An Austrian study with 856 respondents reported that personal gardens are perceived to contribute to restoration of psychological fatigue (Cervinka et al., 2016).

Grasslands at all studied distances $(0.5-5 \mathrm{~km})$ contributed to allergy symptoms, even though the data were not recorded during the grass pollen season. It is possible that the appearance of individual trees in wood-pastures, making up 2\% of the terrain in Belgium (Plieninger et al., 2015), contribute to tree pollen exposure. Nearby forests, within 0.5 and $1 \mathrm{~km}$ distance, contribute to allergy symptoms, while forests further away, within a distance of 2 or $5 \mathrm{~km}$ are not associated with more symptoms. Nevertheless the allergenic trees in forests within a $2-5 \mathrm{~km}$ distance do contribute to symptoms. Airborne pollen can travel over longer distances, hence pollen sources at 
343 a 2-5 km distance can contribute to allergy symptoms (Bogawski et al., 2019). Grasslands may 344 therefore also contribute to tree pollen allergy symptoms by transmitting, rather than emitting, tree 345 pollen, because there is no high vegetation that is able to intercept airborne pollen. In-situ 346 measurements of airborne pollen may be used to elucidate this hypothesis.

\subsection{Strengths and limitations}

349 A main strength of this analysis is the size of the available dataset. During the tree pollen seasons 350 of 2017 and 2018 we tracked 157 adults sensitized to pollen of Alnus, Betula and Corylus.

351 Participants were recruited all over Belgium. The collective effort of the participants resulted in a 352 total of 4714 symptom days.

353 The available geodataset with detailed information on specific green space types allows for more 354 thematic analyses and insights as opposed to a remotely sensed vegetation index such as greenness 355 estimated by NDVI, which has often been used in previous studies. In addition, we had information 356 on the density of allergenic tree species which is extremely relevant for our panel of adults with 357 tree pollen allergy.

358 Most previous studies on the association between green space and mental health outcomes used 359 general populations. A strength of this study is that we were able to study the impact of green space 360 exposure during symptom days on the mental health of allergy patients.

362 Nevertheless, the study has certain limitations such as: self-reported data may be prone to recall 363 bias or mono-method bias and there are possible covariates such as air pollution that are not 364 currently considered. 
365 Self-reported symptom scores using the Likert scales can be subject to a certain level of 366 subjectivity. Nevertheless, this approach could easily be integrated into the smartphone application 367 and is often favored over Visual Analog Scales because of the simplicity of Likert scales.

368 The available densities of allergenic trees were limited to forest plots. Data on the presence of 369 allergenic trees in streets, parks, vacant lots, and private gardenswould be a valuable contribution 370 to this exposure study.

371

\section{5. Conclusion}

373 Distress and perceived stress of 157 adults with pollen allergy exhibited various associations with 374 the extent and composition of green space types around their residence. Increased cover of green 375 space around the residence was protective against distress and perceived stress. However, high 376 amounts of allergenic tree species in nearby forests were a risk factor for distress in tree pollen 377 allergy patients. Higher residential green cover and presence of allergenic trees was also associated 378 with more severe allergy symptoms. Our results contribute evidence for mental health benefits of 379 green space, also for pollen allergy sufferers. There are, however, risks related to specific tree 380 species for both mental and respiratory health during the pollen season which must be further 381 elaborated into recommendations for design of allergy-friendly urban green spaces and other city 382 greening (Aerts et al., 2021; Cariñanos et al., 2019; Jochner-Oette et al., 2018). Moreover, apart 383 from residential green areas sensu stricto also more distant green areas should be taken into account 384 (Jochner-Oette et al., 2018), since we find associations up to a distance of $5 \mathrm{~km}$ while pollen can 385 travel over even larger distances. 


\section{6. Ethical clearance}

388 This study was registered with the Clinical Trial Center of the KU Leuven University Hospital as 389 a national, monocentric, non-commercial study commissioned by the Belgian Science Policy 390 Office BELSPO (study number S59404). The protocol for this study was approved by the Ethical 391 Commission of the KU Leuven University Hospital (Belgian registration number 392 B322201629692). Informed consent was obtained and documented.

\section{Data Statement}

395 The research data is confidential. The land cover data that were used to quantify residential green 396 space (Top10Vector, identifier BE.NGI-IGN/5F4130E6-DF5C-41E6-A956-BB9F04088D11) are 397 copyrighted (CInstitut Géographique National) and were used under federal use license 398 2016_F014 granted by the Institut Géographique National (NGI-IGN) to the Belgian Science 399 Policy Office (BELSPO). 


\section{References}

Aerts, R., Bruffaerts, N., Somers, B., Demoury, C., Plusquin, M., Nawrot, T.S., Hendrickx, M., 2021. Tree pollen allergy risks and changes across scenarios in urban green spaces in Brussels, Belgium. Landsc. Urban Plan. 207, 104001. https://doi.org/10.1016/j.landurbplan.2020.104001

Aerts, R., Dujardin, S., Nemery, B., Van Nieuwenhuyse, A., Van Orshoven, J., Aerts, J.M., Somers, B., Hendrickx, M., Bruffaerts, N., Bauwelinck, M., Casas, L., Demoury, C., Plusquin, M., Nawrot, T.S., 2020a. Residential green space and medication sales for childhood asthma: A longitudinal ecological study in Belgium. Environ. Res. 189, 109914. https://doi.org/10.1016/j.envres.2020.109914

Aerts, R., Honnay, O., Van Nieuwenhuyse, A., 2018. Biodiversity and human health: mechanisms and evidence of the positive health effects of diversity in nature and green spaces. Br. Med. Bull. 127, 5-22. https://doi.org/10.1093/bmb/ldy021

Aerts, R., Stas, M., Vanlessen, N., Hendrickx, M., Bruffaerts, N., Hoebeke, L., Dendoncker, N., Dujardin, S., Saenen, N.D., Van Nieuwenhuyse, A., Aerts, J.-M., Van Orshoven, J., Nawrot, T.S., Somers, B., 2020b. Residential green space and seasonal distress in a cohort of tree pollen allergy patients. Int. J. Hyg. Environ. Health 223, 71-79. https://doi.org/10.1016/j.ijheh.2019.10.004

Agay-Shay, K., Peled, A., Crespo, A.V., Peretz, C., Amitai, Y., Linn, S., Friger, M., Nieuwenhuijsen, M.J., 2014. Green spaces and adverse pregnancy outcomes. Occup. Environ. Med. 71, 562-569. https://doi.org/10.1136/oemed-2013-101961

Alcock, I., White, M., Cherrie, M., Wheeler, B., Taylor, J., McInnes, R., Otte im Kampe, E., 
Vardoulakis, S., Sarran, C., Soyiri, I., Fleming, L., 2017. Land cover and air pollution are associated with asthma hospitalisations: A cross-sectional study. Environ. Int. 109, 29-41. https://doi.org/10.1016/j.envint.2017.08.009

Andrusaityte, S., Grazuleviciene, R., Kudzyte, J., Bernotiene, A., Dedele, A., Nieuwenhuijsen, M.J., 2016. Associations between neighbourhood greenness and asthma in preschool children in Kaunas, Lithuania: A case-control study. BMJ Open 6, e010341. https://doi.org/10.1136/bmjopen-2015-010341

Blaiss, M.S., Hammerby, E., Robinson, S., Kennedy-Martin, T., Buchs, S., 2018. The burden of allergic rhinitis and allergic rhinoconjunctivitis on adolescents: A literature review. Ann. Allergy, Asthma Immunol. https://doi.org/10.1016/j.anai.2018.03.028

Bogawski, P., Borycka, K., Grewling, Ł., Kasprzyk, I., 2019. Detecting distant sources of airborne pollen for Poland: Integrating back-trajectory and dispersion modelling with a satellite-based phenology. Sci. Total Environ. 689, 109-125. https://doi.org/10.1016/j.scitotenv.2019.06.348

Bratman, G.N., Anderson, C.B., Berman, M.G., Cochran, B., de Vries, S., Flanders, J., Folke, C., Frumkin, H., Gross, J.J., Hartig, T., Kahn, P.H., Kuo, M., Lawler, J.J., Levin, P.S., Lindahl, T., Meyer-Lindenberg, A., Mitchell, R., Ouyang, Z., Roe, J., Scarlett, L., Smith, J.R., van den Bosch, M., Wheeler, B.W., White, M.P., Zheng, H., Daily, G.C., 2019. Nature and mental health: An ecosystem service perspective. Sci. Adv. https://doi.org/10.1126/sciadv.aax0903

Browning, M., Lee, K., 2017. Within What Distance Does “Greenness” Best Predict Physical Health? A Systematic Review of Articles with GIS Buffer Analyses across the Lifespan. 
446

447

448

449

450

451

452

453

454

455

456

457

458

459

460

461

462

463

464

465

466

Cariñanos, Grilo, Pinho, Casares-Porcel, Branquinho, Acil, Andreucci, Anjos, Bianco, Brini, Calaza-Martínez, Calvo, Carrari, Castro, Chiesura, Correia, Gonçalves, Gonçalves, Mexia, Mirabile, Paoletti, Santos-Reis, Semenzato, Vilhar, 2019. Estimation of the Allergenic Potential of Urban Trees and Urban Parks: Towards the Healthy Design of Urban Green Spaces of the Future. Int. J. Environ. Res. Public Health 16, 1357. https://doi.org/10.3390/ijerph16081357

Cervinka, R., Schwab, M., Schönbauer, R., Hämmerle, I., Pirgie, L., Sudkamp, J., 2016. My garden - my mate? Perceived restorativeness of private gardens and its predictors. Urban For. Urban Green. 16, 182-187. https://doi.org/10.1016/j.ufug.2016.01.013

Cox, D., Shanahan, D., Hudson, H., Fuller, R., Anderson, K., Hancock, S., Gaston, K., 2017. Doses of Nearby Nature Simultaneously Associated with Multiple Health Benefits. Int. J. Environ. Res. Public Health 14, 172. https://doi.org/10.3390/ijerph14020172

Cox, D.T.C., Shanahan, D.F., Hudson, H.L., Fuller, R.A., Gaston, K.J., 2018. The impact of urbanisation on nature dose and the implications for human health. Landsc. Urban Plan. 179, 72-80. https://doi.org/10.1016/J.LANDURBPLAN.2018.07.013

D’Amato, G., Vitale, C., Lanza, M., Molino, A., D’Amato, M., 2016. Climate change, air pollution, and allergic respiratory diseases. Curr. Opin. Allergy Clin. Immunol. 16, 434440. https://doi.org/10.1097/ACI.0000000000000301

Dalton, A.M., Jones, A.P., Sharp, S.J., Cooper, A.J.M., Griffin, S., Wareham, N.J., 2016. Residential neighbourhood greenspace is associated with reduced risk of incident diabetes in older people: a prospective cohort study. BMC Public Health 16, 1-10. 
468

469

470

471

472

473

474

475

476

477

478

479

480

481

482

483

484

485

486

487

488

Demoury, C., Thierry, B., Richard, H., Sigler, B., Kestens, Y., Parent, M.E., 2017. Residential greenness and risk of prostate cancer: A case-control study in Montreal, Canada. Environ. Int. 98, 129-136. https://doi.org/10.1016/j.envint.2016.10.024

Eisenman, T.S., Jariwala, S.P., Lovasi, G.S., 2019. Urban trees and asthma: a call for epidemiological research. Lancet Respir. Med. https://doi.org/10.1016/S22132600(19)30193-6

Engemann, K., Pedersen, C.B., Arge, L., Tsirogiannis, C., Mortensen, P.B., Svenning, J.C., 2019. Residential green space in childhood is associated with lower risk of psychiatric disorders from adolescence into adulthood. Proc. Natl. Acad. Sci. U. S. A. 116, 5188-5193. https://doi.org/10.1073/pnas.1807504116

Engemann, K., Pedersen, C.B., Arge, L., Tsirogiannis, C., Mortensen, P.B., Svenning, J.C., 2018. Childhood exposure to green space - A novel risk-decreasing mechanism for schizophrenia? Schizophr. Res. https://doi.org/10.1016/j.schres.2018.03.026

Fong, K.C., Hart, J.E., James, P., 2018. A Review of Epidemiologic Studies on Greenness and Health: Updated Literature Through 2017. Curr. Environ. Heal. reports. https://doi.org/10.1007/s40572-018-0179-y

Gernes, R., Brokamp, C., Rice, G.E., Wright, J.M., Kondo, M.C., Michael, Y.L., Donovan, G.H., Gatziolis, D., Bernstein, D., LeMasters, G.K., Lockey, J.E., Khurana Hershey, G.K., Ryan, P.H., 2019. Using high-resolution residential greenspace measures in an urban environment to assess risks of allergy outcomes in children. Sci. Total Environ. 668, 760-767. https://doi.org/10.1016/J.SCITOTENV.2019.03.009 
Grazuleviciene, R., Dedele, A., Danileviciute, A., Vencloviene, J., Grazulevicius, T., Andrusaityte, S., Uzdanaviciute, I., Nieuwenhuijsen, M.J., 2014. The influence of proximity to city parks on blood pressure in early pregnancy. Int. J. Environ. Res. Public Health 11, 2958-2972. https://doi.org/10.3390/ijerph110302958

Jochner-Oette, S., Stitz, T., Jetschni, J., Cariñanos, P., 2018. The Influence of Individual-Specific Plant Parameters and Species Composition on the Allergenic Potential of Urban Green Spaces. Forests 9, 284. https://doi.org/10.3390/f9060284

Labib, S.M., Lindley, S., Huck, J.J., 2020a. Spatial dimensions of the influence of urban greenblue spaces on human health: A systematic review. Environ. Res. https://doi.org/10.1016/j.envres.2019.108869

Labib, S.M., Lindley, S., Huck, J.J., 2020b. Scale effects in remotely sensed greenspace metrics and how to mitigate them for environmental health exposure assessment. Comput. Environ. Urban Syst. 82, 101501. https://doi.org/10.1016/j.compenvurbsys.2020.101501

Lake, I.R., Jones, N.R., Agnew, M., Goodess, C.M., Giorgi, F., Hamaoui-Laguel, L., Semenov, M.A., Solomon, F., Storkey, J., Vautard, R., Epstein, M.M., 2017. Climate change and future pollen allergy in Europe. Environ. Health Perspect. https://doi.org/10.1289/EHP173

Li, D., Deal, B., Zhou, X., Slavenas, M., Sullivan, W.C., 2018. Moving beyond the neighborhood: Daily exposure to nature and adolescents' mood. Landsc. Urban Plan. 173, 33-43. https://doi.org/10.1016/j.landurbplan.2018.01.009

Livesley, S.J., McPherson, E.G., Calfapietra, C., 2016. The Urban Forest and Ecosystem Services: Impacts on Urban Water, Heat, and Pollution Cycles at the Tree, Street, and City Scale. J. Environ. Qual. 45, 119-124. https://doi.org/10.2134/jeq2015.11.0567 
MacKerron, G., Mourato, S., 2013. Happiness is greater in natural environments. Glob. Environ. Chang. 23, 992-1000. https://doi.org/10.1016/J.GLOENVCHA.2013.03.010

Neill, C., Gerard, J., Arbuthnott, K.D., 2019. Nature contact and mood benefits: contact duration and mood type. J. Posit. Psychol. 14, 756-767. https://doi.org/10.1080/17439760.2018.1557242

Oh, H., Koyanagi, A., Devylder, J.E., Stickley, A., 2018. Seasonal allergies and psychiatric disorders in the United States. Int. J. Environ. Res. Public Health 15. https://doi.org/10.3390/ijerph15091965

Parmes, E., Pesce, G., Sabel, C.E., Baldacci, S., Bono, R., Brescianini, S., D’Ippolito, C., Hanke, W., Horvat, M., Liedes, H., Maio, S., Marchetti, P., Marcon, A., Medda, E., Molinier, M., Panunzi, S., Pärkkä, J., Polańska, K., Prud'homme, J., Ricci, P., Snoj Tratnik, J., Squillacioti, G., Stazi, M.A., Maesano, C.N., Annesi-Maesano, I., 2020. Influence of residential land cover on childhood allergic and respiratory symptoms and diseases: Evidence from 9 European cohorts. Environ. Res. 183, 108953. https://doi.org/10.1016/j.envres.2019.108953

Plieninger, T., Hartel, T., Martín-López, B., Beaufoy, G., Bergmeier, E., Kirby, K., Montero, M.J., Moreno, G., Oteros-Rozas, E., Van Uytvanck, J., 2015. Wood-pastures of Europe: Geographic coverage, social-ecological values, conservation management, and policy implications. Biol. Conserv. https://doi.org/10.1016/j.biocon.2015.05.014

Roe, J., Thompson, C., Aspinall, P., Brewer, M., Duff, E., Miller, D., Mitchell, R., Clow, A., 2013. Green Space and Stress: Evidence from Cortisol Measures in Deprived Urban Communities. Int. J. Environ. Res. Public Health 10, 4086-4103. 
534

535

536

537

538

539

540

541

542

543

544

545

546

547

548

549

550

551

552

553

554

Rufo, J.C., Paciência, I., Ribeiro, A.I., 2019. Green Environments and Allergic Diseases in Children: a Scoping Review. Curr. Epidemiol. Reports 6, 442-448. https://doi.org/10.1007/s40471-019-00218-0

Su, J.G., Dadvand, P., Nieuwenhuijsen, M.J., Bartoll, X., Jerrett, M., 2019. Associations of green space metrics with health and behavior outcomes at different buffer sizes and remote sensing sensor resolutions. Environ. Int. 126, 162-170. https://doi.org/10.1016/j.envint.2019.02.008

Tischer, C., Gascon, M., Fernández-Somoano, A., Tardón, A., Lertxundi Materola, A., Ibarluzea, J., Ferrero, A., Estarlich, M., Cirach, M., Vrijheid, M., Fuertes, E., Dalmau-Bueno, A., Nieuwenhuijsen, M.J., Antó, J.M., Sunyer, J., Dadvand, P., 2017. Urban green and grey space in relation to respiratory health in children. Eur. Respir. J. 49, 1502112. https://doi.org/10.1183/13993003.02112-2015

Triguero-Mas, M., Dadvand, P., Cirach, M., Martínez, D., Medina, A., Mompart, A., Basagaña, X., Gražulevičiene, R., Nieuwenhuijsen, M.J., 2015. Natural outdoor environments and mental and physical health: Relationships and mechanisms. Environ. Int. 77, 35-41. https://doi.org/10.1016/j.envint.2015.01.012

Trikojat, K., Luksch, H., Rösen-Wolff, A., Plessow, F., Schmitt, J., Buske-Kirschbaum, A., 2017. "Allergic mood" - Depressive and anxiety symptoms in patients with seasonal allergic rhinitis (SAR) and their association to inflammatory, endocrine, and allergic markers. Brain. Behav. Immun. 65, 202-209. https://doi.org/10.1016/j.bbi.2017.05.005

Twohig-Bennett, C., Jones, A., 2018. The health benefits of the great outdoors: A systematic 
review and meta-analysis of greenspace exposure and health outcomes. Environ. Res. 166, 628-637. https://doi.org/10.1016/J.ENVRES.2018.06.030

557 Ulmer, J.M., Wolf, K.L., Backman, D.R., Tretheway, R.L., Blain, C.J., O’Neil-Dunne, J.P., 558 Frank, L.D., 2016. Multiple health benefits of urban tree canopy: The mounting evidence 559 for a green prescription. Heal. Place 42, 54-62. https://doi.org/10.1016/j.healthplace.2016.08.011

561 Westra, T., Verschelde, P., Van Calster, H., Els, L., Onkelinx, T., Quataert, P., Govaere, L., 562 Waterinckx, M., 2015. Opmaak van een analysestramien voor de gegevens van de Vlaamse Bosinventarisatie. Brussels. https://doi.org/INBO.R.2015.903482

564 White, M.P., Alcock, I., Wheeler, B.W., Depledge, M.H., 2013. Would You Be Happier Living 565 in a Greener Urban Area? A Fixed-Effects Analysis of Panel Data. Psychol. Sci. 24, 920566 928. https://doi.org/10.1177/0956797612464659 


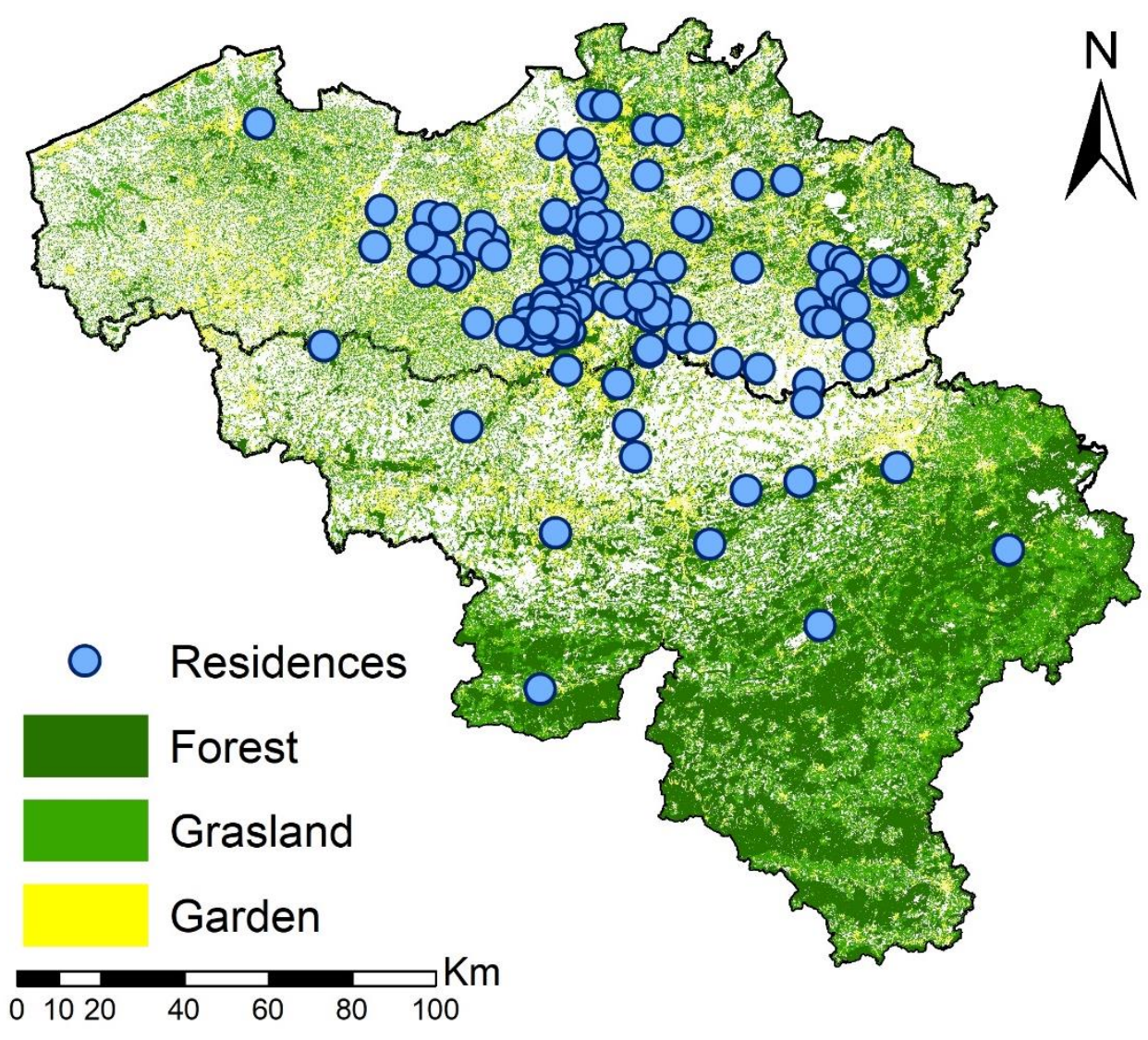

571 Figure S1: Distribution of the 157 participants included in the residential exposure study.

572 Residence symbols are oversized due to privacy restrictions. Forest, grassland and garden data are

573 from the Top10 vector dataset of the Belgian National Geographic Institute. 

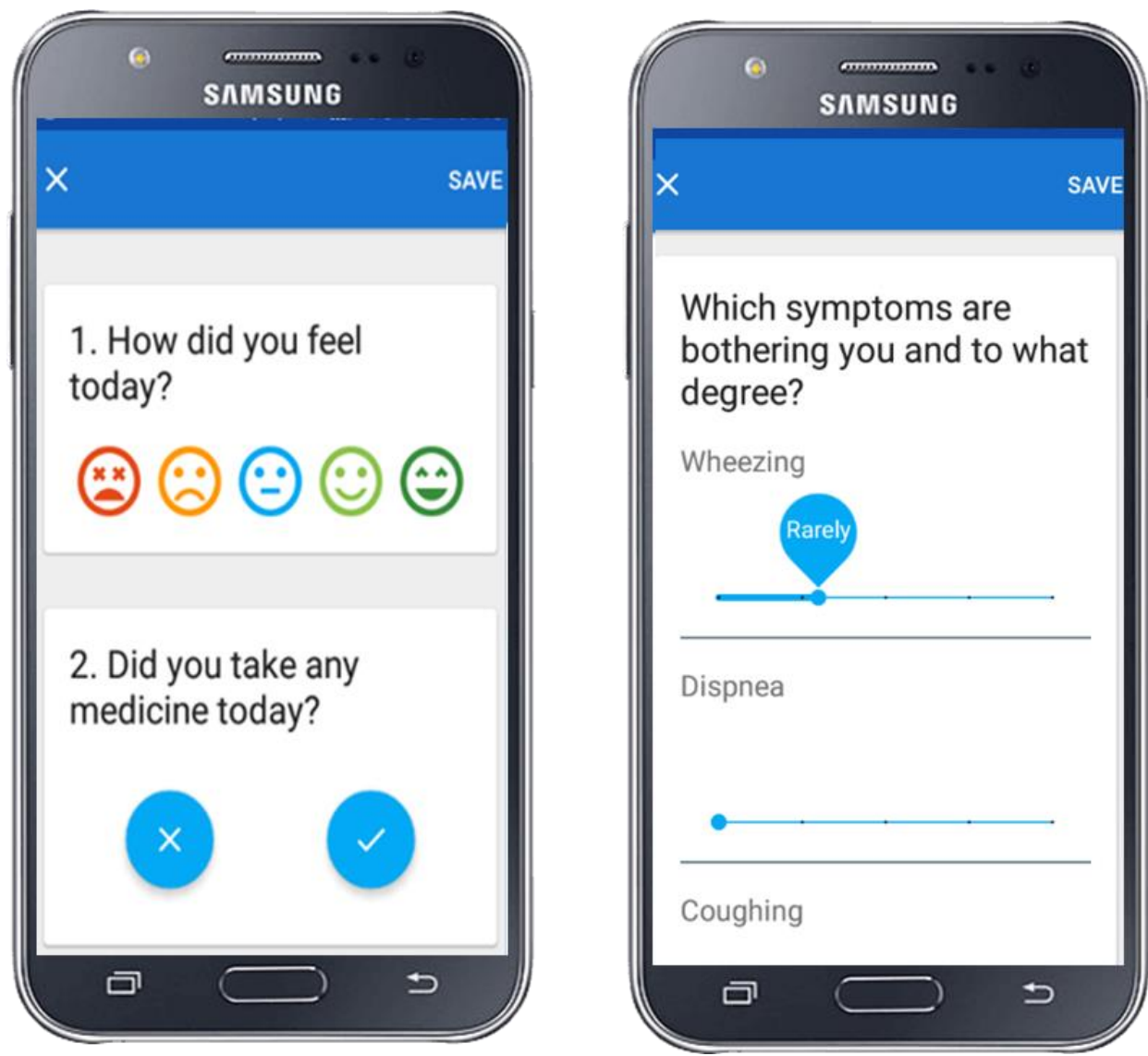

576 Figure S2: Two screenshots from the RespirIT app for android used by the participants to log their 577 mood (left) and allergy symptoms (right) at the end of every day. 
579 Table S1: Beta-coefficients with 95\% confidence intervals for unadjusted models of objective 580 residential green measures in a $0.5,1,2$ and $5 \mathrm{~km}$ radius around the residence. Response variables 581 are the score of the general health questionnaire with 12 questions (GHQ-12), scores of the 582 perceived stress scale (PSS), average mood score (AvgMo) and average symptom score (AvgSy).

583 Significant associations are highlighted in grey boxes.

\begin{tabular}{|c|c|c|c|c|c|}
\hline & Predictor & $\begin{array}{c}\text { Unadjusted } \\
\text { GHQ-12 }\end{array}$ & $\begin{array}{c}\text { Unadjusted } \\
\text { PSS }\end{array}$ & $\begin{array}{c}\text { Unadjusted } \\
\text { AvgMo }\end{array}$ & $\begin{array}{c}\text { Unadjusted } \\
\text { AvgSy }\end{array}$ \\
\hline & & $\beta(95 \%$ CI $)$ & $\beta(95 \%$ CI $)$ & $\beta(95 \%$ CI $)$ & $\beta(95 \%$ CI $)$ \\
\hline \multirow{4}{*}{$\frac{\Xi}{n}$} & Garden (10ha) & $\begin{array}{l}-0.029 \\
(-0.126-0.068)\end{array}$ & $\begin{array}{l}-0.065 \\
(-0.105--0.026)\end{array}$ & $\begin{array}{l}0.011 \\
(-0.012-0.035)\end{array}$ & $\begin{array}{l}0.051 \\
(0.032-0.071)\end{array}$ \\
\hline & Grass (10ha) & $\begin{array}{l}-0.035 \\
(-0.164-0.094)\end{array}$ & $\begin{array}{l}0.023 \\
(-0.025-0.072)\end{array}$ & $\begin{array}{l}-0.008 \\
(-0.040-0.023)\end{array}$ & $\begin{array}{l}0.086 \\
(0.062-0.110)\end{array}$ \\
\hline & Forest (10ha) & $\begin{array}{l}-0.274 \\
(-0.443--0.104)\end{array}$ & $\begin{array}{l}-0.004 \\
(-0.048-0.040)\end{array}$ & $\begin{array}{l}0.014 \\
(-0.013-0.040)\end{array}$ & $\begin{array}{l}0.049 \\
(0.027-0.070)\end{array}$ \\
\hline & Basal Area $\left(\mathrm{m}^{2} / \mathrm{ha}\right)$ & $\begin{array}{l}0.037 \\
(0.001-0.073)\end{array}$ & $\begin{array}{l}0.002 \\
(-0.014-0.017)\end{array}$ & $\begin{array}{l}-0.006 \\
(-0.016-0.004)\end{array}$ & $\begin{array}{l}0.002 \\
(-0.006-0.009)\end{array}$ \\
\hline \multirow{4}{*}{$\Xi$} & Garden (10ha) & $\begin{array}{l}-0.018 \\
(-0.047-0.012)\end{array}$ & $\begin{array}{l}-0.020 \\
(-0.031--0.008)\end{array}$ & $\begin{array}{l}0.003 \\
(-0.004-0.010)\end{array}$ & $\begin{array}{l}0.013 \\
(0.007-0.018)\end{array}$ \\
\hline & Grass (10ha) & $\begin{array}{l}-0.007 \\
(-0.038-0.024)\end{array}$ & $\begin{array}{l}-0.007 \\
(-0.019-0.005)\end{array}$ & $\begin{array}{l}-0.002 \\
(-0.009-0.006)\end{array}$ & $\begin{array}{l}0.020 \\
(0.014-0.026\end{array}$ \\
\hline & Forest (10ha) & $\begin{array}{l}-0.048 \\
(-0.085--0.011)\end{array}$ & $\begin{array}{l}0.000 \\
(-0.011-0.011)\end{array}$ & $\begin{array}{l}0.003 \\
(-0.004-0.010)\end{array}$ & $\begin{array}{l}0.016 \\
(0.010-0.021)\end{array}$ \\
\hline & Basal Area $\left(\mathrm{m}^{2} / \mathrm{ha}\right)$ & $\begin{array}{l}0.010 \\
(-0.010-0.030)\end{array}$ & $\begin{array}{l}-0.007 \\
(-0.015-0.002)\end{array}$ & $\begin{array}{l}-0.002 \\
(-0.007-0.003)\end{array}$ & $\begin{array}{l}0.005 \\
(0.001-0.009)\end{array}$ \\
\hline \multirow{4}{*}{$\frac{\Xi}{N}$} & Garden (10ha) & $\begin{array}{l}0.000 \\
(-0.010-0.009) \\
\end{array}$ & $\begin{array}{l}-0.003 \\
(-0.007-0.000)\end{array}$ & $\begin{array}{l}0.000 \\
(-0.002-0.002)\end{array}$ & $\begin{array}{l}0.005 \\
(0.003-0.006)\end{array}$ \\
\hline & Grass (10ha) & $\begin{array}{l}-0.003 \\
(-0.012-0.006) \\
\end{array}$ & $\begin{array}{l}-0.005 \\
(-0.009--0.001) \\
\end{array}$ & $\begin{array}{l}0.000 \\
(-0.003-0.002)\end{array}$ & $\begin{array}{l}0.006 \\
(0.005-0.008)\end{array}$ \\
\hline & Forest (10ha) & $\begin{array}{l}-0.023 \\
(-0.034--0.012)\end{array}$ & $\begin{array}{l}-0.001 \\
(-0.004-0.003)\end{array}$ & $\begin{array}{l}0.001 \\
(-0.001-0.003)\end{array}$ & $\begin{array}{l}0.000 \\
(-0.001-0.002)\end{array}$ \\
\hline & Basal Area $\left(\mathrm{m}^{2} / \mathrm{ha}\right)$ & $\begin{array}{l}0.020 \\
(0.014-0.027) \\
\end{array}$ & $\begin{array}{l}0.003 \\
(0.000-0.006) \\
\end{array}$ & $\begin{array}{l}0.000 \\
(-0.002-0.002)\end{array}$ & $\begin{array}{l}0.007 \\
(0.007-0.008)\end{array}$ \\
\hline \multirow{4}{*}{$\frac{\Xi}{n}$} & Garden (10ha) & $\begin{array}{l}0.001 \\
(-0.002-0.003)\end{array}$ & $\begin{array}{l}0.000 \\
(-0.001-0.000)\end{array}$ & $\begin{array}{l}0.000 \\
(-0.001-0.000)\end{array}$ & $\begin{array}{l}0.000 \\
(0.000-0.001)\end{array}$ \\
\hline & Grass (10ha) & $\begin{array}{l}0.000 \\
(-0.002-0.002)\end{array}$ & $\begin{array}{l}-0.001 \\
(-0.001-0.000)\end{array}$ & $\begin{array}{l}0.000 \\
(-0.001-0.000)\end{array}$ & $\begin{array}{l}0.001 \\
(0.001-0.002)\end{array}$ \\
\hline & Forest (10ha) & $\begin{array}{l}-0.001 \\
(-0.003-0.000)\end{array}$ & $\begin{array}{l}0.001 \\
(0.000-0.001)\end{array}$ & $\begin{array}{l}0.000 \\
(0.000-0.000)\end{array}$ & $\begin{array}{l}0.000 \\
(0.000-0.000)\end{array}$ \\
\hline & Basal Area $\left(\mathrm{m}^{2} / \mathrm{ha}\right)$ & $\begin{array}{l}0.000 \\
(-0.002-0.002)\end{array}$ & $\begin{array}{l}-0.001 \\
(-0.001-0.000)\end{array}$ & $\begin{array}{l}0.000 \\
(0.000-0.000)\end{array}$ & $\begin{array}{l}0.001 \\
(0.001-0.002)\end{array}$ \\
\hline
\end{tabular}



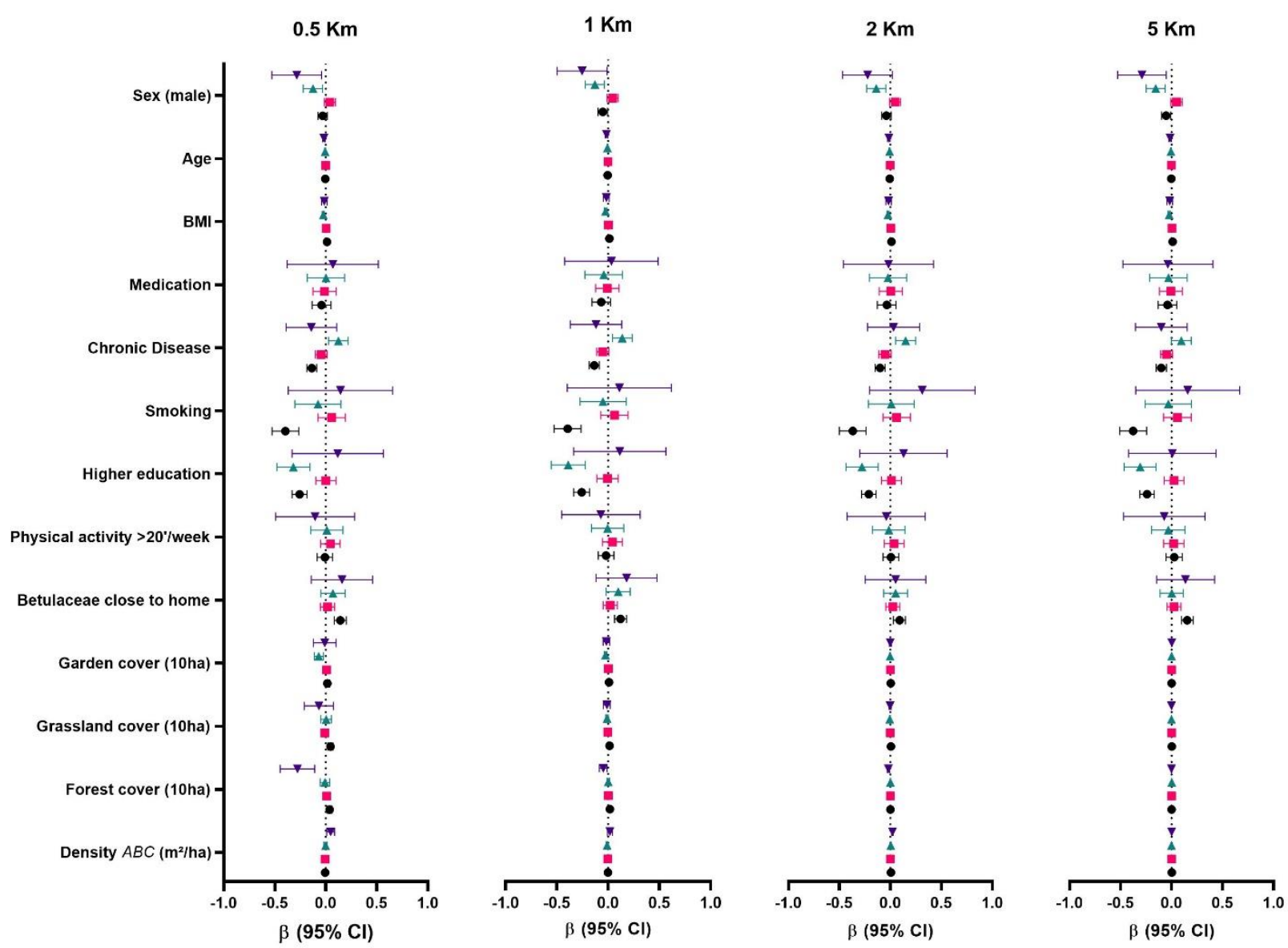

586 Figure S3: Fully adjusted associations (beta-coefficients with 95\% confidence interval limits) between health outcomes and predictors 587 for residential exposure models of $1 \mathrm{~km}, 2 \mathrm{~km}$ and $5 \mathrm{~km}$ radius around the residence. The response variables are the score of the general 588 health questionnaire with 12 questions (GHQ-12), scores of the perceived stress scale (PSS), average mood score on symptom days 589 (AvgMo) and average symptom score on symptom days (AvgSy). 
591 Table SError! No text of specified style in document.2: Beta-coefficients with 95\% confidence 592 intervals for unadjusted models of objective residential green measures in a 0.5, 1, 2 and $5 \mathrm{~km}$ 593 radius around the residence. Response variables are the score of the general health questionnaire 594 with 12 questions (GHQ-12), scores of the perceived stress scale (PSS), average mood score on 595 symptom days (AvgMo) and average symptom score on symptom days (AvgSy). Data from a 596 cohort of allergy patients in Belgium. Significant associations are highlighted in grey boxes.

\begin{tabular}{|c|c|c|c|c|c|}
\hline & Predictor & $\begin{array}{c}\text { Fully adjusted } \\
\text { GHQ-12 }\end{array}$ & $\begin{array}{c}\text { Fully adjusted } \\
\text { PSS }\end{array}$ & $\begin{array}{c}\text { Fully adjusted } \\
\text { AvgMo }\end{array}$ & $\begin{array}{c}\text { Fully adjusted } \\
\text { AvgSy }\end{array}$ \\
\hline & & $\beta(95 \%$ CI $)$ & $\beta(95 \%$ CI $)$ & $\beta(95 \%$ CI) & $\beta(95 \%$ CI $)$ \\
\hline \multirow[t]{10}{*}{$\begin{array}{l}0.5 \\
\mathrm{~km}\end{array}$} & female & (reference) & (reference) & (reference) & (reference) \\
\hline & male & $\begin{array}{l}-0.285 \\
(-0.528--0.043)\end{array}$ & $\begin{array}{l}-0.126 \\
(-0.222--0.031)\end{array}$ & $\begin{array}{l}0.039 \\
(-0.016-0.095)\end{array}$ & $\begin{array}{l}-0.030 \\
(-0.077-0.016)\end{array}$ \\
\hline & Age (years) & $\begin{array}{l}-0.018 \\
(-0.030--0.005)\end{array}$ & $\begin{array}{l}-0.007 \\
(-0.011--0.002)\end{array}$ & $\begin{array}{l}-0.001 \\
(-0.003-0.002)\end{array}$ & $\begin{array}{l}-0.005 \\
(-0.007--0.002)\end{array}$ \\
\hline & BMI & $\begin{array}{l}-0.015 \\
(-0.043-0.013)\end{array}$ & $\begin{array}{l}-0.024 \\
(-0.035--0.013)\end{array}$ & $\begin{array}{l}0.003 \\
(-0.003-0.010)\end{array}$ & $\begin{array}{l}0.012 \\
(0.006-0.017)\end{array}$ \\
\hline & $\begin{array}{r}\text { Medication } \\
\text { no }\end{array}$ & (reference) & (reference) & (reference) & (reference) \\
\hline & yes & $\begin{array}{l}0.069 \\
(-0.378-0.515)\end{array}$ & $\begin{array}{l}0.002 \\
(-0.181-0.185)\end{array}$ & $\begin{array}{l}-0.013 \\
(-0.126-0.101)\end{array}$ & $\begin{array}{l}-0.042 \\
(-0.133-0.050)\end{array}$ \\
\hline & $\begin{array}{c}\text { Chronic Disease } \\
\text { no }\end{array}$ & (reference) & (reference) & (reference) & (reference) \\
\hline & yes & $\begin{array}{l}-0.142 \\
(-0.390-0.106)\end{array}$ & $\begin{array}{l}0.123 \\
(0.027-0.218)\end{array}$ & $\begin{array}{l}-0.045 \\
(-0.103-0.013)\end{array}$ & $\begin{array}{l}-0.137 \\
(-0.186--0.089)\end{array}$ \\
\hline & $\begin{array}{r}\text { Smoking } \\
\text { no }\end{array}$ & (reference) & (reference) & (reference) & (reference) \\
\hline & yes & $\begin{array}{l}0.144 \\
(-0.368-0.655)\end{array}$ & $\begin{array}{l}-0.077 \\
(-0.303-0.149)\end{array}$ & $\begin{array}{l}0.057 \\
(-0.077-0.191)\end{array}$ & $\begin{array}{l}-0.396 \\
(-0.527--0.265)\end{array}$ \\
\hline
\end{tabular}




\begin{tabular}{|c|c|c|c|c|c|}
\hline & $\begin{array}{c}\text { Higher education } \\
\text { no }\end{array}$ & (reference) & (reference) & (reference) & (reference) \\
\hline & yes & $\begin{array}{l}0.117 \\
(-0.330-0.564)\end{array}$ & $\begin{array}{l}-0.318 \\
(-0.480--0.156)\end{array}$ & $\begin{array}{l}0.000 \\
(-0.099-0.100)\end{array}$ & $\begin{array}{l}-0.257 \\
(-0.331--0.184)\end{array}$ \\
\hline & $\begin{array}{l}\text { Physical activity } \\
(>20 \text { '/week }) \\
\text { no }\end{array}$ & (reference) & (reference) & (reference) & (reference) \\
\hline & yes & $\begin{array}{l}-0.105 \\
(-0.491-0.282)\end{array}$ & $\begin{array}{l}0.010 \\
(-0.148-0.168)\end{array}$ & $\begin{array}{l}0.045 \\
(-0.051-0.141)\end{array}$ & $\begin{array}{l}-0.008 \\
(-0.084-0.068)\end{array}$ \\
\hline & $\begin{array}{c}\text { Betulaceae nearby } \\
\text { no }\end{array}$ & (reference) & (reference) & (reference) & (reference) \\
\hline & yes & $\begin{array}{l}0.159 \\
(-0.142-0.459)\end{array}$ & $\begin{array}{l}0.070 \\
(-0.048-0.189)\end{array}$ & $\begin{array}{l}0.017 \\
(-0.053-0.087)\end{array}$ & $\begin{array}{l}0.142 \\
(0.083-0.201)\end{array}$ \\
\hline & Garden (10ha) & $\begin{array}{l}-0.010 \\
(-0.120-0.100)\end{array}$ & $\begin{array}{l}-0.070 \\
(-0.113--0.026)\end{array}$ & $\begin{array}{l}0.007 \\
(-0.019-0.033)\end{array}$ & $\begin{array}{l}0.016 \\
(-0.005-0.038)\end{array}$ \\
\hline & Grass (10ha) & $\begin{array}{l}-0.067 \\
(-0.211-0.076)\end{array}$ & $\begin{array}{l}0.003 \\
(-0.049-0.054)\end{array}$ & $\begin{array}{l}-0.010 \\
(-0.043-0.023)\end{array}$ & $\begin{array}{l}0.045 \\
(0.021-0.070)\end{array}$ \\
\hline & Forest (10ha) & $\begin{array}{l}-0.277 \\
(-0.447--0.108)\end{array}$ & $\begin{array}{l}-0.008 \\
(-0.054-0.037)\end{array}$ & $\begin{array}{l}0.009 \\
(-0.018-0.037)\end{array}$ & $\begin{array}{l}0.038 \\
(0.015-0.060)\end{array}$ \\
\hline & Density $A B C\left(\mathrm{~m}^{2} / \mathrm{ha}\right)$ & $\begin{array}{l}0.047 \\
(0.008-0.086)\end{array}$ & $\begin{array}{l}-0.002 \\
(-0.019-0.014)\end{array}$ & $\begin{array}{l}-0.007 \\
(-0.018-0.003)\end{array}$ & $\begin{array}{l}-0.006 \\
(-0.014-0.002)\end{array}$ \\
\hline $\begin{array}{c}1 \\
\mathrm{~km}\end{array}$ & female & (reference) & (reference) & (reference) & (reference) \\
\hline & male & $\begin{array}{l}-0.254 \\
(-0.496--0.011)\end{array}$ & $\begin{array}{l}-0.129 \\
(-0.223--0.035)\end{array}$ & $\begin{array}{l}0.044 \\
(-0.011-0.099)\end{array}$ & $\begin{array}{l}-0.052 \\
(-0.098--0.007)\end{array}$ \\
\hline & Age (years) & $\begin{array}{l}-0.017 \\
(-0.029--0.004)\end{array}$ & $\begin{array}{l}-0.006 \\
(-0.011--0.001)\end{array}$ & $\begin{array}{l}-0.001 \\
(-0.004-0.002)\end{array}$ & $\begin{array}{l}-0.005 \\
(-0.007--0.002)\end{array}$ \\
\hline & BMI & $\begin{array}{l}-0.017 \\
(-0.045-0.011)\end{array}$ & $\begin{array}{l}-0.025 \\
(-0.037--0.014)\end{array}$ & $\begin{array}{l}0.004 \\
(-0.003-0.010)\end{array}$ & $\begin{array}{l}0.012 \\
(0.007-0.017)\end{array}$ \\
\hline & $\begin{array}{r}\text { Medication } \\
\text { no }\end{array}$ & (reference) & (reference) & (reference) & (reference) \\
\hline
\end{tabular}




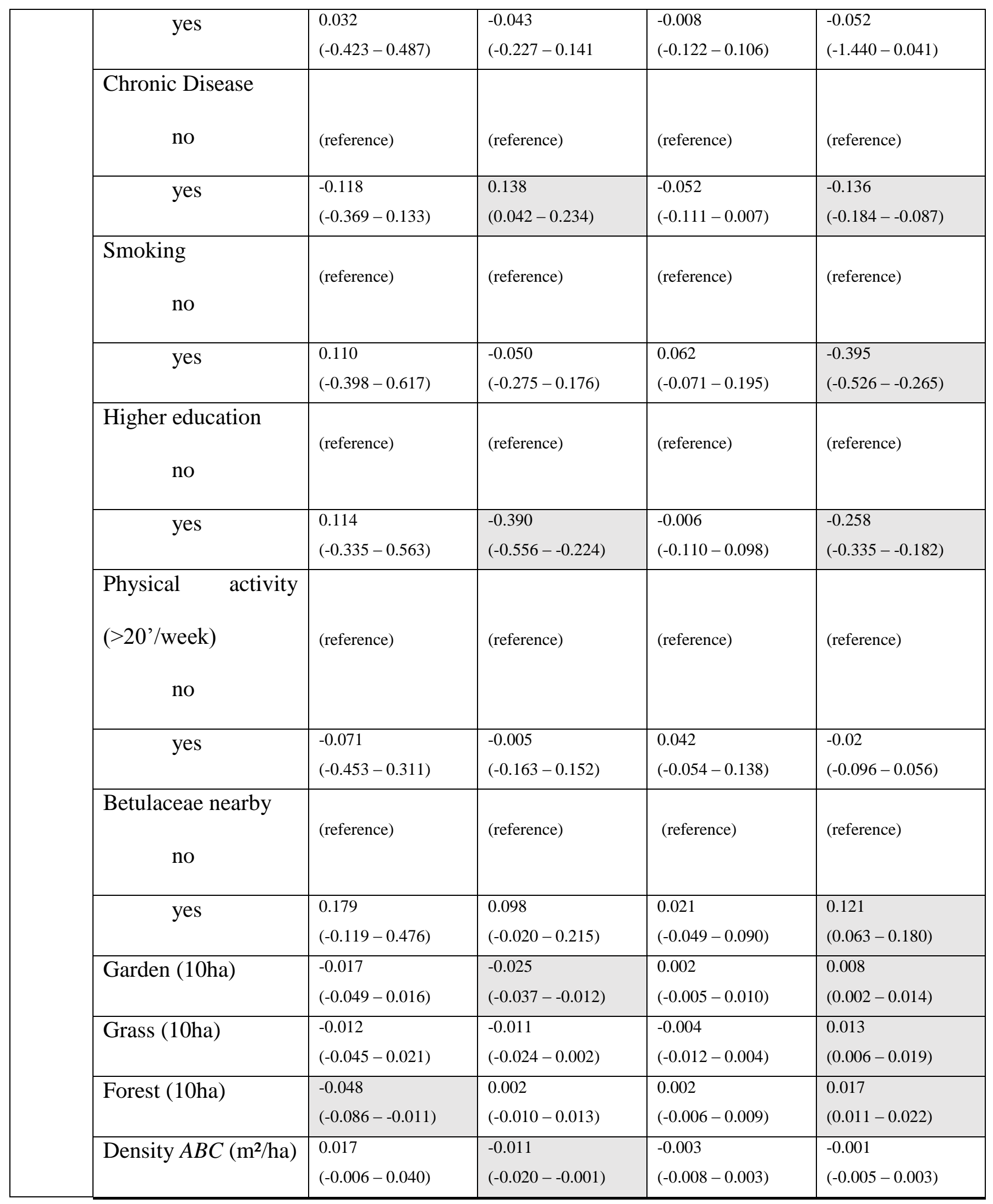




\begin{tabular}{|c|c|c|c|c|c|}
\hline \multirow[t]{15}{*}{$2 \mathrm{~km}$} & female & (reference) & (reference) & (reference) & (reference) \\
\hline & male & $\begin{array}{l}-0.224 \\
(-0.469-0.020)\end{array}$ & $\begin{array}{l}-0.139 \\
(-0.233--0.046)\end{array}$ & $\begin{array}{l}0.047 \\
(-0.008-0.102)\end{array}$ & $\begin{array}{l}-0.040 \\
-0.085-0.006\end{array}$ \\
\hline & Age (years) & $\begin{array}{l}-0.016 \\
(-0.028--0.004)\end{array}$ & $\begin{array}{l}-0.008 \\
(-0.013--0.003)\end{array}$ & $\begin{array}{l}-0.001 \\
(-0.004-0.002)\end{array}$ & $\begin{array}{l}-0.006 \\
(-0.008--0.003)\end{array}$ \\
\hline & BMI & $\begin{array}{l}-0.018 \\
(-0.046-0.009)\end{array}$ & $\begin{array}{l}-0.023 \\
(-0.034--0.012)\end{array}$ & $\begin{array}{l}0.004 \\
(-0.003-0.010)\end{array}$ & $\begin{array}{l}0.011 \\
(0.006-0.017)\end{array}$ \\
\hline & $\begin{array}{r}\text { Medication } \\
\text { no }\end{array}$ & (reference) & (reference) & (reference) & (reference) \\
\hline & yes & $\begin{array}{l}-0.018 \\
(-0.460-0.423)\end{array}$ & $\begin{array}{l}-0.023 \\
(-0.206-0.160)\end{array}$ & $\begin{array}{l}0.003 \\
(-0.110-0.116)\end{array}$ & $\begin{array}{l}-0.036 \\
(-0.128-0.055)\end{array}$ \\
\hline & $\begin{array}{c}\text { Chronic disease } \\
\text { no }\end{array}$ & (reference) & (reference) & (reference) & (reference) \\
\hline & yes & $\begin{array}{l}0.031 \\
(-0.225-0.287)\end{array}$ & $\begin{array}{l}0.149 \\
(0.051-0.247)\end{array}$ & $\begin{array}{l}-0.053 \\
(-0.113-0.007)\end{array}$ & $\begin{array}{l}-0.102 \\
(-0.151-0.052)\end{array}$ \\
\hline & $\begin{array}{r}\text { Smoking } \\
\text { no } \\
\end{array}$ & (reference) & (reference) & (reference) & (reference) \\
\hline & yes & $\begin{array}{l}0.312 \\
(-0.205-0.828)\end{array}$ & $\begin{array}{l}0.008 \\
(-0.217-0.234)\end{array}$ & $\begin{array}{l}0.061 \\
(-0.073-0.195)\end{array}$ & $\begin{array}{l}-0.370 \\
(-0.502--0.239)\end{array}$ \\
\hline & $\begin{array}{c}\text { Higher education } \\
\text { no }\end{array}$ & (reference) & (reference) & (reference) & (reference) \\
\hline & yes & $\begin{array}{l}0.129 \\
(-0.300-0.558)\end{array}$ & $\begin{array}{l}-0.279 \\
(-0.436--0.121)\end{array}$ & $\begin{array}{l}0.010 \\
(-0.088-0.107)\end{array}$ & $\begin{array}{l}-0.211 \\
(-0.282--0.140)\end{array}$ \\
\hline & $\begin{array}{l}\text { Physical activity } \\
(>20 \text { '/week) } \\
\text { no }\end{array}$ & (reference) & (reference) & (reference) & (reference) \\
\hline & yes & $\begin{array}{l}-0.041 \\
(-0.424-0.341)\end{array}$ & $\begin{array}{l}-0.016 \\
(-0.176-0.143)\end{array}$ & $\begin{array}{l}0.036 \\
(-0.060-0.133)\end{array}$ & $\begin{array}{l}0.005 \\
(-0.072-0.082)\end{array}$ \\
\hline & $\begin{array}{c}\text { Betulaceae nearby } \\
\text { no }\end{array}$ & (reference) & (reference) & (reference) & (reference) \\
\hline
\end{tabular}




\begin{tabular}{|c|c|c|c|c|c|}
\hline & yes & $\begin{array}{l}0.051 \\
(-0.246-0.347)\end{array}$ & $\begin{array}{l}0.051 \\
(-0.066-0.167)\end{array}$ & $\begin{array}{l}0.024 \\
(-0.045-0.093)\end{array}$ & $\begin{array}{l}0.090 \\
(0.031-0.148)\end{array}$ \\
\hline & Garden (10ha) & $\begin{array}{l}-0.001 \\
(-0.011-0.009)\end{array}$ & $\begin{array}{l}-0.004 \\
(-0.008-0.000)\end{array}$ & $\begin{array}{l}0.000 \\
(-0.002-0.003)\end{array}$ & $\begin{array}{l}0.004 \\
(0.002-0.006)\end{array}$ \\
\hline & Grass (10ha) & $\begin{array}{l}-0.003 \\
(-0.013-0.006)\end{array}$ & $\begin{array}{l}-0.006 \\
(-0.009-0.002)\end{array}$ & $\begin{array}{l}-0.001 \\
(-0.003-0.001)\end{array}$ & $\begin{array}{l}0.005 \\
(0.003-0.007)\end{array}$ \\
\hline & Forest (10ha) & $\begin{array}{l}-0.020 \\
(-0.030--0.009)\end{array}$ & $\begin{array}{l}0.000 \\
(-0.004-0.003)\end{array}$ & $\begin{array}{l}0.000 \\
(-0.002-0.002)\end{array}$ & $\begin{array}{l}0.000 \\
(-0.001-0.002)\end{array}$ \\
\hline & Basal Area $\left(\mathrm{m}^{2} / \mathrm{ha}\right)$ & $\begin{array}{l}0.021 \\
(0.014-0.028)\end{array}$ & $\begin{array}{l}0.003 \\
(0.000-0.007)\end{array}$ & $\begin{array}{l}0.000 \\
(-0.002-0.001)\end{array}$ & $\begin{array}{l}0.005 \\
(0.004-0.007)\end{array}$ \\
\hline \multirow[t]{11}{*}{$5 \mathrm{~km}$} & female & (reference) & (reference) & (reference) & (reference) \\
\hline & male & $\begin{array}{l}-0.291 \\
(-0.530--0.052)\end{array}$ & $\begin{array}{l}-0.156 \\
(-0.249--0.062)\end{array}$ & $\begin{array}{l}0.048 \\
(-0.006-0.103)\end{array}$ & $\begin{array}{l}-0.054 \\
(-0.099--0.008)\end{array}$ \\
\hline & Age (years) & $\begin{array}{l}-0.015 \\
(-0.027--0.003)\end{array}$ & $\begin{array}{l}-0.007 \\
(-0.012--0.002)\end{array}$ & $\begin{array}{l}-0.001 \\
(-0.004-0.002)\end{array}$ & $\begin{array}{l}-0.004 \\
(-0.006--0.002)\end{array}$ \\
\hline & BMI & $\begin{array}{l}-0.018 \\
(-0.046-0.011)\end{array}$ & $\begin{array}{l}-0.024 \\
(-0.036--0.013)\end{array}$ & $\begin{array}{l}0.003 \\
(-0.003-0.010)\end{array}$ & $\begin{array}{l}0.011 \\
(0.006-0.017)\end{array}$ \\
\hline & $\begin{array}{r}\text { Medication } \\
\text { no }\end{array}$ & (reference) & (reference) & (reference) & (reference) \\
\hline & yes & $\begin{array}{l}-0.037 \\
(-0.478-0.404)\end{array}$ & $\begin{array}{l}-0.031 \\
(-0.215-0.153)\end{array}$ & $\begin{array}{l}-0.007 \\
(-0.121-0.107)\end{array}$ & $\begin{array}{l}-0.041 \\
(-0.132-0.051)\end{array}$ \\
\hline & $\begin{array}{c}\text { Chronic disease } \\
\text { no }\end{array}$ & (reference) & (reference) & (reference) & (reference) \\
\hline & yes & $\begin{array}{l}-0.101 \\
(-0.354-0.152)\end{array}$ & $\begin{array}{l}0.095 \\
(-0.003-0.192)\end{array}$ & $\begin{array}{l}-0.049 \\
(-0.108-0.011)\end{array}$ & $\begin{array}{l}-0.101 \\
(-0.150--0.051)\end{array}$ \\
\hline & $\begin{array}{r}\text { Smoking } \\
\text { no }\end{array}$ & (reference) & (reference) & (reference) & (reference) \\
\hline & yes & $\begin{array}{l}0.158 \\
(-0.352-0.668)\end{array}$ & $\begin{array}{l}-0.033 \\
(-0.259-0.193)\end{array}$ & $\begin{array}{l}0.057 \\
(-0.078-0.191)\end{array}$ & $\begin{array}{l}-0.377 \\
(-0.508--0.245)\end{array}$ \\
\hline & $\begin{array}{c}\text { Higher education } \\
\text { no }\end{array}$ & (reference) & (reference) & (reference) & (reference) \\
\hline
\end{tabular}




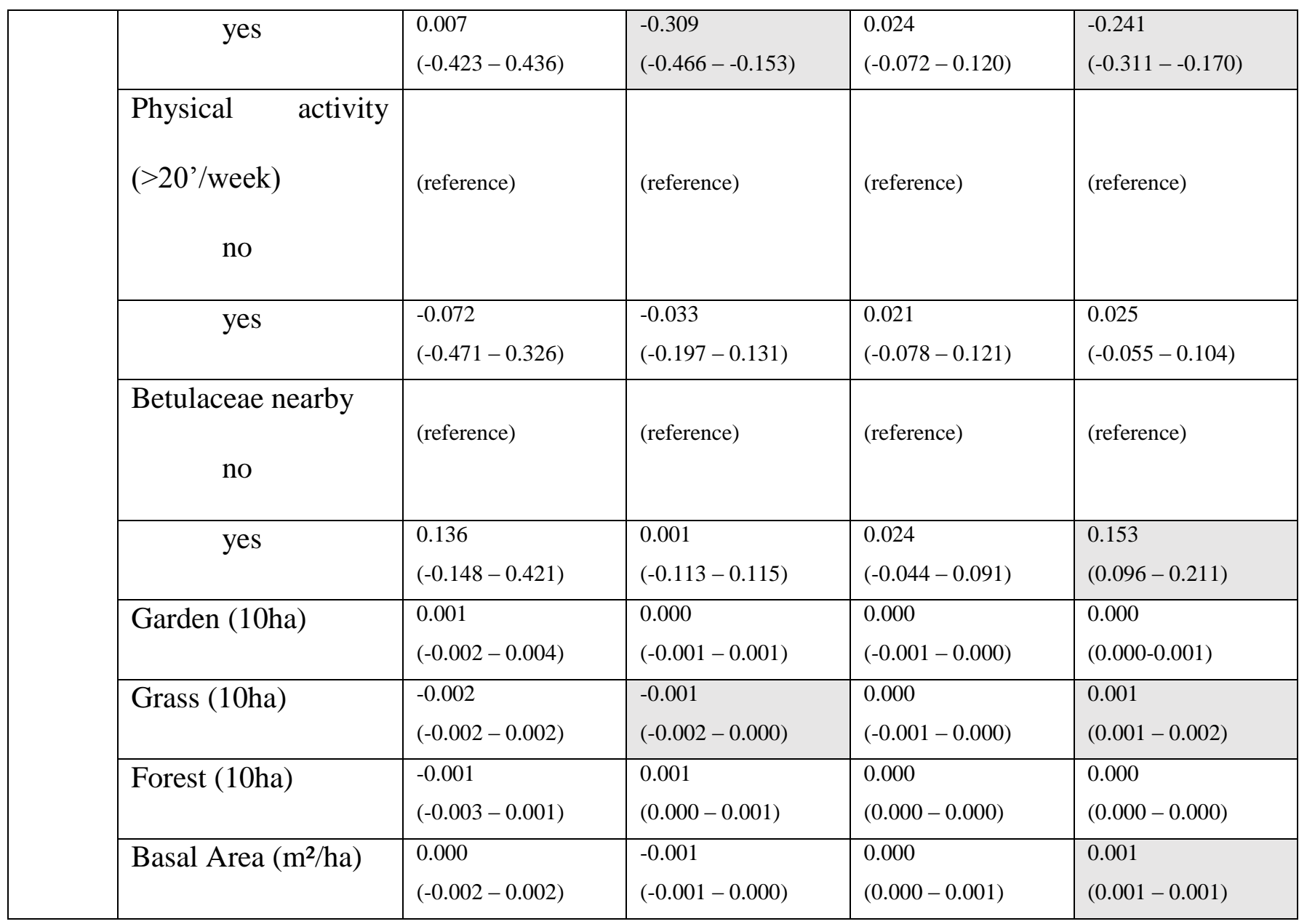

597 
599 Table S3: Beta-coefficients with 95\% confidence intervals for adjusted models of objective 600 residential green measures in a $0.5,1,2$ and $5 \mathrm{~km}$ radius around the residence, adjusted for average 601 symptom score (AvgSy). Response variables are the score of the general health questionnaire with 60212 questions (GHQ-12) and scores of the perceived stress scale (PSS). Significant associations are 603 highlighted in grey boxes.

\begin{tabular}{|c|c|c|c|}
\hline & Predictor & GHQ-12 & PSS \\
\hline & & $\beta(95 \% \mathrm{CI})$ & $\beta(95 \%$ CI $)$ \\
\hline \multirow{5}{*}{$\frac{\Xi}{n}$} & AvgSy & $0.005(0.003-0.008)$ & $0.002(0.001-0.003)$ \\
\hline & Garden (10ha) & $-0.020(-0.127-0.087)$ & $-0.001(-0.052-0.051)$ \\
\hline & Grass (10ha) & $-0.077(-0.222-0.067)$ & $-0.013(-0.058-0.031)$ \\
\hline & Forest (10ha) & $-0.261(-0.424--0.099)$ & $-0.001(-0.018-0.015)$ \\
\hline & Basal Area $\left(\mathrm{m}^{2} / \mathrm{ha}\right)$ & $0.042(0.003-0.081)$ & $-0.069(-0.112--0.026)$ \\
\hline \multirow{5}{*}{$\Xi$} & AvgSy & $0.006(0.003-0.008)$ & $0.002(0.001-0.003)$ \\
\hline & Garden (10ha) & $-0.022(-0.053-0.010)$ & $-0.025(-0.038--0.013)$ \\
\hline & Grass (10ha) & $-0.015(-0.048-0.018)$ & $-0.012(-0.025-0.001)$ \\
\hline & Forest (10ha) & $-0.050(-0.086--0.014)$ & $-0.001(-0.012-0.010)$ \\
\hline & Basal Area $\left(\mathrm{m}^{2} / \mathrm{ha}\right)$ & $0.016(-0.008-0.039)$ & $-0.010(-0.019--0.001)$ \\
\hline \multirow{5}{*}{$\frac{\Xi}{N}$} & AvgSy & $0.004(0.001-0.007)$ & $0.002(0.001-0.003)$ \\
\hline & Garden (10ha) & $-0.003(-0.013-0.007)$ & $-0.004(-0.008--0.001)$ \\
\hline & Grass (10ha) & $-0.004(-0.015-0.005)$ & $-0.006(-0.010--0.002)$ \\
\hline & Forest (10ha) & $-0.018(-0.028--0.008)$ & $-0.001(-0.004-0.003)$ \\
\hline & Basal Area $\left(\mathrm{m}^{2} / \mathrm{ha}\right)$ & $0.018(0.011-0.025)$ & $0.003(0.000-0.006)$ \\
\hline \multirow{5}{*}{$\frac{\Xi}{n}$} & AvgSy & $0.005(0.003-0.008)$ & $0.002(0.001-0.004)$ \\
\hline & Garden (10ha) & $0.001(-0.002-0.004)$ & $0.000(-0.001-0.001)$ \\
\hline & Grass (10ha) & $0.000(-0.002-0.002)$ & $-0.001(-0.002-0.000)$ \\
\hline & Forest (10ha) & $-0.001(-0.003-0.001)$ & $0.001(0.000-0.001)$ \\
\hline & Basal Area $\left(\mathrm{m}^{2} / \mathrm{ha}\right)$ & $0.000(-0.002-0.002)$ & $-0.001(-0.002-0.000)$ \\
\hline
\end{tabular}

604 
606

607

608

609

\begin{tabular}{|l|l|l|l|l|l|l|l|l|}
\cline { 2 - 9 } \multicolumn{1}{c|}{} & \multicolumn{5}{c|}{ Unadjusted } & \multicolumn{3}{c|}{ Adjusted } \\
\cline { 2 - 9 } & $\mathbf{0 . 5} \mathbf{~ k m}$ & $\mathbf{1 ~ k m}$ & $\mathbf{2 ~ k m}$ & $\mathbf{5 ~ k m}$ & $\mathbf{0 . 5} \mathbf{~ k m}$ & $\mathbf{1 ~ k m}$ & $\mathbf{2 ~ k m}$ & $\mathbf{5} \mathbf{~ k m}$ \\
\hline AVG.SY & 4521.50 & 4503.43 & 4393.19 & 4430.29 & 4369.66 & 4346.99 & 4281.08 & 4285.29 \\
\hline PSS & 1225.64 & 1225.79 & 1227.59 & 1226.19 & 1188.95 & 1179.73 & 1184.92 & 1185.39 \\
\hline GHQ12 & 775.88 & 781.28 & 753.78 & 786.95 & 769.14 & 776.48 & 750.44 & 785.83 \\
\hline AVG.MO & 1021.59 & 1022.81 & 1024.67 & 1021.96 & 1030.99 & 1031.05 & 1032.56 & 1031.60 \\
\hline
\end{tabular}

Table S4: Comparison of model quality using Akaike's Information Criterion (AIC) for the unadjusted and adjusted models developed at different scales $(0.5,1,2$ and $5 \mathrm{~km}$ radius). The response variables are the score of the 12-item General Health Questionnaire (GHQ-12), score of the Perceived Stress Scale (PSS), average mood score (AvgMo) and average symptom score (AvgSy).

610 


\section{Acknowledgments}

This study was carried out in the framework of the RespirIT project, which has been supported financially by the Belgian Science Policy Office BELSPO (grant nr. BR/154/A1/RespirIT). 